\title{
Viruses in Cancers of the Digestive System: Active Contributors or Idle Bystanders?
}

\author{
Martin Marônek ${ }^{1}\left(\mathbb{D}\right.$, René Link ${ }^{2}$, Giovanni Monteleone ${ }^{3}$, Roman Gardlík ${ }^{1}(\mathbb{D}$ and \\ Carmine Stolfi ${ }^{3,4, * \text { (D) }}$ \\ 1 Institute of Molecular Biomedicine, Faculty of Medicine, Comenius University, 81108 Bratislava, Slovakia; \\ martin.maronek@gmail.com (M.M.); romangardlik@gmail.com (R.G.) \\ 2 Institute of Experimental Medicine, Faculty of Medicine, University of Pavol Jozef Šafárik, \\ 04011 Košice, Slovakia; rlink4@gmail.com \\ 3 Department of Systems Medicine, University of Rome “Tor Vergata”, 00133 Rome, Italy; \\ gi.monteleone@med.uniroma2.it \\ 4 Division of Clinical Biochemistry and Clinical Molecular Biology, University of Rome "Tor Vergata", \\ 00133 Rome, Italy \\ * Correspondence: carmine.stolfi@uniroma2.it; Tel.: +39-06-72596163
}

Received: 30 September 2020; Accepted: 29 October 2020; Published: 30 October 2020

\begin{abstract}
The human virome, which is a collection of all the viruses that are present in the human body, is increasingly being recognized as an essential part of the human microbiota. The human gastrointestinal tract and related organs (e.g., liver, pancreas, and gallbladder)—composing the gastrointestinal (or digestive) system - contain a huge number of viral particles which contribute to maintaining tissue homeostasis and keeping our body healthy. However, perturbations of the virome steady-state may, both directly and indirectly, ignite/sustain oncogenic mechanisms contributing to the initiation of a dysplastic process and/or cancer progression. In this review, we summarize and discuss the available evidence on the association and role of viruses in the development of cancers of the digestive system.
\end{abstract}

Keywords: virome; phages; eukaryotic viruses; colorectal cancer; HBV; HCV; HPV; EBV; p53; $\mathrm{Wnt} / \beta$-catenin

\section{Introduction}

The human microbiota represents one of the most complex ecosystems on Earth, spanning bacteria, archaea, fungi, and viruses. Such microbes have coevolved with humans for millions of years, influencing our development and shaping, in particular, our immune defenses [1]. Despite this, for many years, there was modest interest in the microbiota among researchers and it is only in the last decade that it has become a major research area. Nowadays, the microbiota is considered to be crucial for our immune, hormonal, and metabolic homeostasis, and perturbations in its composition contribute to the emergence of various diseases, such as inflammatory bowel diseases, obesity, and metabolic syndrome [2].

The human virome, which is a collection of all the viruses that are present in the human body [3], is increasingly being recognized as an essential part of the human microbiota and emerging as a new and interesting field of study due to recent advances in the detection and characterization of the viral genome within the background of the ample human genome. The virome composition changes within different organs/tissues, as each compartment of the body is characterized by a distinctive microenvironment. In addition, the viral communities are influenced by both endogenous and exogenous factors, such as age, diet, and the presence of other components of the microbiota $[4,5]$. 
The human gastrointestinal tract and related organs (e.g., liver, pancreas, and gallbladder) — composing the gastrointestinal (or digestive) system — contain a huge number of viral particles (estimated to be more than $10^{15}$ ) [6,7], which contribute to maintaining tissue homeostasis and keeping our body healthy [8]. However, virome steady-state perturbations may ignite different diseases, such as hepatitis and inflammatory bowel diseases (IBDs), and recent research is shedding light on the role of viral entities in promoting dysplasia and ultimately, cancer.

In this review, we summarize and discuss the available evidence on the association and role of viruses in the initiation and development of cancers of the gastrointestinal system.

\section{Human Virome: Main Players}

A virome includes all of the nucleic acids (single-stranded DNA, double-stranded DNA, single-stranded RNA, and double-stranded RNA) belonging to the viruses associated with a particular ecosystem [9]. Such viruses can generally be distinguished based on the host preference, with virtually any form of life potentially acting as a host. The human gut virome is established soon after birth and comprises a diverse collection of viral particles that infect both prokaryotic and eukaryotic cells [3]. Research has mainly focused on two groups of viruses: bacteriophages (or phages), which infect bacteria and overwhelm the other classes in terms of abundance, and eukaryotic viruses (hereinafter referred to as viruses), which infect our own cells. Although their importance cannot be underestimated, other components of the gut virome, such as viruses that infect protozoans, fungi, archaea, and even other viruses, are not as deeply studied as the above-mentioned groups due to a limited understanding of their function within the environment of the human body [10]. By either directly affecting host cell behavior/viability or by preying upon certain species of bacteria, with the ultimate result of altering bacterial communities, enteric viruses contribute to the homeostasis of the digestive apparatus. For instance, it has been shown that intestinal abnormalities of germ-free mice were alleviated following infection of the animals with the murine norovirus strain CR6 [11]. Moreover, the pretreatment of mice with antiviral drugs resulted in more severe colitis in a mouse model of dextran sulphate sodium-induced colitis [12]. On the other hand, some members of the gut virome may contribute, either directly or indirectly, such as via increasing the frequency of mutations, chromosomal rearrangements, and insertional mutagenesis, to the emergence and development of cancers [13].

\subsection{Phages}

As bacterial predators, phages extensively contribute to the abundance and composition of the gut microbiota and have been mainly studied for their impact on intestinal inflammation, as in the case of Crohn's disease and ulcerative colitis $[14,15]$. To date, several studies have suggested that phages may be an active driving force of gut carcinogenesis [16]. One possibility in this regard is that they act via modulation of the local microenvironment of the alimentary canal in a fashion that promotes the invasion and proliferation of oncogenic bacteria [16]. One opportunistic bacteria which has already been implicated in gastrointestinal cancer is Fusobacterium nucleatum [17]. Alternatively, phages may be immunogenic, as a high presence of phage DNA has been shown to aggravate ulcerative colitis via the engagement of Toll-like receptors (TLRs) and interferon- $\gamma$ production [18]. Phages can employ two different cycles to infect and modulate the bacterial population-lytic and lysogenic — and can even switch between them on certain occasions [19]. In the lytic cycle, the infection of bacteria results in destruction of the infected cell and the subsequent release of viral progeny. In the lysogenic cycle, the genomic material of the phage randomly integrates into the host genome and remains there as a prophage replicating along with it. This process, known as horizontal gene transfer, provides bacteria with additional genes [20]. Such genes may code toxins and/or products, facilitating, among other things, bacterial mucosal adhesion, evasion from the host immune system, resistance to antibiotics, and/or the invading ability [21-23]. Such transformed bacteria could potentially cause tissue damage, inflammation, and progression toward carcinogenesis. On the other hand, tumor-specific phage particles have been reported to promote tumor regression/destruction in mouse melanoma 
models $[24,25]$ and phage therapy has even been considered as a plausible treatment option for human cancer [26]. In this context, protein-protein interaction between GP24 of T4 and HAP1 phages and integrin $\beta 3$ or the HSP90 receptor of cancer cells was shown to inhibit metastasis in melanoma and lung cancer in murine (B16 and LLC) and human (HS294T and A549) cell lines [27,28]. Interestingly, under certain circumstances, the interaction between phages and human cells may be important for phage infection. Shan et al. reported that phage phiCDHS1 killed the pathogen Clostridium difficile faster when placed in a culture of human colon cancer cells [29]. Furthermore, this interaction appeared to be cell-specific, since HeLa cells did not confer the observed effect [29]. Overall, it remains to be determined which interactions and under which circumstances phages are potentially harmful or protective in the development of gastrointestinal cancer.

\subsection{Viruses}

Viruses can infect all the cells of our body and other eukaryotic organisms colonizing our digestive tract. The diversity of such viruses is commonly evaluated by determining the viral families or species in a given sample. This is usually expressed as the number of reads as a surrogate of their relative abundance. Among the DNA viruses, some can establish persistent infections, such as those belonging to the Herpesviridae family, whereas others, such as Anelloviruses, have not been associated with a specific pathology [30]. In contrast, RNA viruses seem to cause acute infections. However, as the majority of metagenomic studies have focused on DNA viruses, it is possible that RNA virus families are also widely distributed in the human body. Persistent viruses are of particular importance since they can establish a long-term relationship with their host and influence the inflammatory status of the body. Such a persistent inflammatory condition can promote, in some cases, a carcinogenic milieu that favors the genesis and development of cancer cells [31,32]. Tumor viruses acting by shaping the immune system towards the production of carcinogenic and/or immune-suppressive cytokines/factors are referred to as indirect carcinogens [33]. On the other hand, viruses that are capable of incorporating their genetic information into the human DNA-a process that can result in the dysregulation of oncogenes and/or inactivation of tumor suppressive genes-are referred to as direct carcinogens [33]. However, it is important to point out that direct and indirect mechanisms of virus-driven carcinogenesis are not mutually exclusive and some tissues may be equally dependent on both mechanisms for oncogenic transformation, such as the liver and stomach [13]. While current evidence strongly suggests a role of certain viruses, e.g., Epstein-Barr virus (EBV) in the pathogenesis of lymphoma in IBD patients [34] or human papillomavirus (HPV) in cervical cancer [35], the role of these and other viruses in gastrointestinal cancer remains less clear.

\section{Role of Viruses in the Development of Cancers of the Gastrointestinal System}

In the last two decades, researchers have attempted to unravel the potential link between virus infection and cancer development. While most of the studies in this regard only aimed at detecting the presence of viral particles in cancer patients, some aimed to shed light on the interaction/causality between putative tumor viruses and transformed cells. The associations of specific viruses with cancers of the gastrointestinal tract and related organs, as well as the virus-driven molecular mechanisms (potentially contributing to the emergence/development of such malignancies), are summarized in Table 1 and discussed below. 
Table 1. Overview of the most relevant studies investigating potential associations between viruses and cancers of the digestive system.

\begin{tabular}{|c|c|c|c|c|c|c|c|}
\hline First Author & Year & Virus & Cancer Type & Sample Origin & $\begin{array}{l}\text { Number of } \\
\text { Samples }\end{array}$ & Observation & Ref. \\
\hline Maden & 1992 & HPV & Oral & USA & 131 & $\begin{array}{l}\text { HPV-6 is associated with } \\
\text { oral cancer }\end{array}$ & [36] \\
\hline Jalouli & 2012 & HPV, HSV, EBV & Oral & $\begin{array}{l}\text { UK, Sweden, } \\
\text { Sudan, Norway, } \\
\text { USA, Yemen, } \\
\text { India, Sri Lanka }\end{array}$ & 155 & $\begin{array}{c}\text { Higher proportion of samples } \\
\text { with HSV and EBV in } \\
\text { industrialized countries }\end{array}$ & [37] \\
\hline Bjørge & 1997 & $\mathrm{HPV}$ & Esophageal & Norway & 228 & $\begin{array}{l}\text { Increased risk of developing } \\
\text { cancer among } \\
\text { HPV-16-seropositive subjects }\end{array}$ & [38] \\
\hline Zhang & 2015 & HPV & Esophageal & China & 3044 & $\mathrm{HPV}-16$ is a possible risk factor & [39] \\
\hline Wang & 2010 & $\mathrm{HPV}$ & Esophageal & China, USA & 435 & $\begin{array}{l}\text { HPV infection is common in } \\
\text { esophageal carcinoma, } \\
\text { independent of region and } \\
\text { ethnic group of origin }\end{array}$ & {$[40]$} \\
\hline Kirgan & 1990 & $\mathrm{HPV}$ & Colorectal & USA & 90 & $\begin{array}{l}\text { Association between HPV and } \\
\text { colon neoplasia }\end{array}$ & {$[41]$} \\
\hline Lee & 2001 & HPV & Colorectal & Taiwan & 38 & $\mathrm{HPV}-18$ is a possible risk factor & [42] \\
\hline Alexandrou & 2014 & $\mathrm{HPV}$ & Anal & Greece & 11 & $\begin{array}{l}\text { Lower incidence of HPV in anal } \\
\text { cancer compared to other } \\
\text { Western countries }\end{array}$ & [43] \\
\hline Kabarriti & 2019 & $\mathrm{HPV}$ & Anal & USA & 5927 & $\begin{array}{l}\text { HPV is a significant prognostic } \\
\text { marker in anal cancer, especially } \\
\text { for locally advanced disease }\end{array}$ & [44] \\
\hline Muresu & 2020 & HPV & Anal & Italy & 30 & $\mathrm{HPV}$ is a possible risk factor & [45] \\
\hline Awerkiew & 2003 & HPV, EBV & Esophageal & Germany & 37 & $\begin{array}{l}\text { EBV, but not HPV, was detected } \\
\text { in esophageal cancer samples }\end{array}$ & {$[46]$} \\
\hline Martínez-López & 2014 & EBV & Gastric & Mexico & 297 & $\begin{array}{l}\text { Possible role for EBV in gastric } \\
\text { cancer and early } \\
\text { precursor lesions. }\end{array}$ & [47] \\
\hline
\end{tabular}


Table 1. Cont.

\begin{tabular}{|c|c|c|c|c|c|c|c|}
\hline First Author & Year & Virus & Cancer Type & Sample Origin & $\begin{array}{l}\text { Number of } \\
\text { Samples }\end{array}$ & Observation & Ref. \\
\hline Corallo & 2020 & EBV & Gastric & Italy & 175 & $\begin{array}{l}\text { Patients with EBV-positive } \\
\text { gastric cancer who did not } \\
\text { receive ICI had a better response } \\
\text { to first-line chemotherapy and } \\
\text { better survival compared with } \\
\text { EBV-negative patients }\end{array}$ & [48] \\
\hline $\mathrm{Li}$ & 2004 & EBV & Hepatic & China & 141 & $\begin{array}{c}\text { Presence of HBV infection in } \\
\text { HCC tissues }\end{array}$ & [49] \\
\hline Song & 2006 & EBV & Colorectal & China & 115 & $\begin{array}{l}\text { Possible association of EBV with } \\
\text { colorectal carcinoma }\end{array}$ & [50] \\
\hline Fiorina & 2014 & $\begin{array}{l}\text { HPV, EBV, JCV, } \\
\text { BKV }\end{array}$ & Colorectal & Italy & 44 & $\begin{array}{c}\text { No or weak association of HPV, } \\
\text { EBV, JCV, and BKV with } \\
\text { colorectal cancer }\end{array}$ & [51] \\
\hline Laghi & 1999 & $\mathrm{JCV}$ & Colorectal & USA & 23 & $\begin{array}{l}\text { JCV DNA may play a role in } \\
\text { the chromosomal instability } \\
\text { observed in colorectal } \\
\text { carcinogenesis }\end{array}$ & [52] \\
\hline Hori & 2005 & $\mathrm{JCV}$ & Colorectal & Japan & 64 & $\begin{array}{l}\text { Possible role of JCV in colorectal } \\
\text { carcinogenesis }\end{array}$ & [53] \\
\hline Jung & 2008 & $\mathrm{JCV}$ & Colorectal & USA & 74 & $\begin{array}{l}\text { JCV T-Antigen is expressed in } \\
\text { the early stage of colorectal } \\
\text { cancer }\end{array}$ & [54] \\
\hline Tokita & 2002 & TTV & Hepatic & Japan & 237 & $\begin{array}{l}\text { High TTV abundance is } \\
\text { an independent risk factor }\end{array}$ & [55] \\
\hline Iloeje & 2010 & $\mathrm{HBV}$ & Pancreatic & Taiwan & 22,471 & $\begin{array}{l}\text { Chronic HBV infection may be } \\
\text { associated with an increased } \\
\text { risk of pancreatic cancer }\end{array}$ & [56] \\
\hline Zhou & 2012 & $\mathrm{HBV}, \mathrm{HCV}$ & Bile duct & $\begin{array}{l}\text { Meta-analyses } \\
\text { (13 case-control } \\
\text { studies and } 3 \\
\text { cohort studies) }\end{array}$ & - & $\begin{array}{l}\mathrm{HBV} \text { and } \mathrm{HCV} \text { are risk factors } \\
\text { in bile duct cancer }\end{array}$ & [57] \\
\hline
\end{tabular}


Table 1. Cont.

\begin{tabular}{|c|c|c|c|c|c|c|c|}
\hline First Author & Year & Virus & Cancer Type & Sample Origin & $\begin{array}{c}\text { Number of } \\
\text { Samples }\end{array}$ & Observation & Ref. \\
\hline Hassan & 2008 & HBV & Pancreatic & USA & 476 & $\begin{array}{l}\text { Past exposure to HBV is } \\
\text { a possible risk factor in } \\
\text { pancreatic cancer }\end{array}$ & {$[58]$} \\
\hline $\mathrm{Su}$ & 2020 & HBV & Colorectal & Taiwan & 69,478 & $\begin{array}{l}\text { Chronic HBV infection is } \\
\text { strongly associated with } \\
\text { increased risk of developing } \\
\text { colorectal cancer }\end{array}$ & [59] \\
\hline Dimberg & 2013 & $\mathrm{CMV}$ & Colorectal & Sweden, Vietnam & 202 & $\begin{array}{c}\text { CMV DNA rate was } \\
\text { significantly higher in } \\
\text { cancerous tissues compared to } \\
\text { normal tissues }\end{array}$ & [60] \\
\hline Chen & 2016 & CMV & Colorectal & Taiwan & 556 & $\begin{array}{c}\text { More favorable disease-free } \\
\text { survival rate in non-elderly } \\
\text { patients with CMV-positive } \\
\text { tumors, specifically in patients } \\
\text { with stage III disease }\end{array}$ & [61] \\
\hline Chen & 2015 & $\mathrm{CMV}$ & Colorectal & $\begin{array}{l}\text { USA, France, Italy, } \\
\text { Japan, China, } \\
\text { Taiwan }\end{array}$ & 92 & $\begin{array}{c}\text { Specific genetic CMV } \\
\text { polymorphisms are associated } \\
\text { with different clinical outcomes }\end{array}$ & [62] \\
\hline Jin & 2019 & HIV & Anal & Australia & Not applicable & $\begin{array}{l}\text { People living with HIV are at } \\
\text { markedly higher risk of } \\
\text { anal cancer }\end{array}$ & [63] \\
\hline Colón-López & 2018 & HIV & Anal & USA & Not applicable & $\begin{array}{l}\text { Anal cancer incidence is } \\
\text { markedly elevated among } \\
\text { people with HIV infection }\end{array}$ & [64] \\
\hline Grew & 2015 & HIV & Anal & USA & Not applicable & $\begin{array}{l}\text { HIV-positive patients had } \\
\text { significantly worse overall and } \\
\text { colostomy-free survival rates } \\
\text { than HIV-negative patients }\end{array}$ & [65] \\
\hline
\end{tabular}




\subsection{Oral Cancer}

Compared to other cancers of the digestive system, oral cancer (OC) has a lower worldwide incidence [66]. However, this statistic does not mean that less attention should be directed toward it. The oral cavity comes into contact with food on a daily basis, which is a source of bacteria and viruses. Saliva helps digest the food, moistens it to favor the passage into the stomach, and acts as a protective layer for the surrounding tissue. Many OC cases are attributed to smoking and dietary habits [67]. In this context, the consumption of betel quid, which contains areca nut and tobacco, is believed to be partially responsible for the higher occurrence of cases of oral submucous fibrosis and $\mathrm{OC}$ in the Indian population compared with people from other countries [68]. Certain viruses, such as HPV, have been suggested to play a role in the development of OC. In 1992, a study by Maden and coworkers reported a 2.9-fold and 6.2-fold higher risk of developing OC for men who were positive for HPV-6 and HPV-16, respectively [36]. Since then, HPV has been suggested to account for as much as $30 \%$ of all OC cases [69]. However, there is considerable variability in the results of HPV prevalence in the published literature. For instance, Kouvousi et al. found that the HPV prevalence in OC samples is $11 \%$ [70]. In the same paper, the mRNA expression of HPV E6 and E7 genes, which are known protooncogenes, was reported in almost $9 \%$ of the cases [70]. On the other hand, HPV prevalence as high as $65 \%$ has been reported in OC patients in a Swedish study [37]. Accumulating evidence seems to indicate that OC-associated viral infections are linked to certain geographical areas where a virus reaches a higher prevalence. In a study by Jalouli et al., the prevalence of HPV, EBV, and herpes simplex virus (HSV) was compared in OC samples [37]. When considering all of the samples, 55\%, $35 \%$, and $15 \%$ of them were positive for EBV, HPV, and HSV, respectively. HPV was most abundant in Sudan, reaching a prevalence of $65 \%$, whereas both EBV and HSV were most prevalent in the United Kingdom (with values of $80 \%$ and $55 \%$, respectively). Of note, single infections with HSV and EBV, as well as co-infections with the same viruses, occurred at a significantly higher proportion in samples taken from patients inhabiting industrialized countries (e.g., Sweden, Norway, the United Kingdom, and the USA) compared with samples taken from patients living in developing countries (e.g., Sudan, India, Sri Lanka, and Yemen) [37]. Data indicating a probable role of HPV in the rise of OC were obtained by González-Ramírez and colleagues, who found a two-times higher presence of HPV DNA in the Mexican population with a diagnosis of OC compared to controls (5\% vs. 2.5\%, respectively). It is noteworthy that OC patients presented no additional risk factors, such as alcohol consumption or smoking [71]. Subsequently, a meta-analysis performed in India reported HPV positivity in almost $40 \%$ of patients bearing OC — with an odds ratio of 2.82 - thus indicating a significantly higher risk of developing OC for HPV-positive patients compared with the general population [72]. None of the standard clinicopathological variables (e.g., age, sex, smoking and oral tobacco history, grade, or site) were predictive for HPV positivity [73].

Interestingly, the percentage of HPV-positive OC patients without any history of oral tobacco use was more than $31 \%$, whereas only $10 \%$ of OC patients with previous oral tobacco use tested positive for HPV infection [73].

Mechanistically, recent research has been focusing on elucidating potential viral interactions with oncogenic signaling pathways. For instance, the overexpression of $\mathrm{p} 16-\mathrm{a}$ tumor suppressor protein-has been detected in OC samples and suggested to act as a possible surrogate marker for infections with high-risk HPV strains [74]. Several reports have highlighted the importance of p53 in HPV infections with regards to p53 mutations [75] or the p53 expression status [76], or as an association with poor patient survival [77]. Taken together, although causative evidence remains elusive, the above studies indicate a strong association between HPV infection and a higher risk of developing OC.

\subsection{Esophageal Cancer}

Esophageal cancer (EC) usually manifests as either esophageal adenocarcinoma (EAC) or esophageal squamous cell carcinoma (ESCC) [78]. The notion that HPV may be involved in EC arose when its presence was discovered in specimens taken from patients with this neoplasia [79]. 
However, there is no clear evidence to date indicating that the presence of HPV represents a risk factor for the development of EC, as reports are controversial. In 1997, a prospective study by Bjørge et al. found an increased risk of developing EC among HPV-16-positive subjects in Norway [38]. Conversely, two years later, a Swedish nationwide case-control study of HPV-16 and HPV-18 did not report any association between HPV and either EAC or ESCC, even when adjusted for additional factors such as smoking or alcohol consumption [80]. In line with this latter evidence, the occurrence of HPV (both high- and low-risk phenotypes) did not differ between ESCC and control samples in Poland [81]. Observational studies from China declared that HPV infection is independent of region and ethnic group [40] and range from stating that HPV infection may be a risk factor [39] to suggesting that HPV infection has a causative role in the development of EC [82]. Other regional studies from Iran [83], Turkey and Somalia [84], Colombia and Chile [85], Brazil [86], and Australia [87] confirmed the presence of HPV in either EC or both controls and EC samples. Adding to the regional inconsistency, one study from Brazil did not find any HPV-positive ESCC samples [88] and another identified only a few HPV-infected samples in Australia [89]. In a study by Chang et al., the analysis of cytomegalovirus (CMV) and HSV was included, in addition to HPV and EBV. However, only HPV positivity was found in all of the carcinomas [90]. In a Chinese cohort, $\mathrm{Xi}$ et al. reported a significantly higher HPV16 E6 expression in ESCC patients compared to controls. In the former, a positive HPV16 infection status negatively correlated with 3- and 5-year overall survival, as well as with progression-free survival [91]. Given such data, the authors even suggested that HPV infection may represent a marker for predicting the prognosis of ESCC patients. Taken together, the above reports indicate a higher prevalence of HPV in EC specimens than in controls, which may suggest a certain role of HPV in the development of EC. However, the causality of this observation has not yet been elucidated. Concerning the role of EBV in EC, most studies agree that EBV infection is not involved in or does not correlate with the development of EAC and ESCC [92-97], although a German study by Awerkiew et al. reported that EC was associated with EBV, but not with HPV [46].

Although the mechanisms of conversion of normal squamous cells to carcinoma cells have not been completely elucidated, some studies have highlighted the role of several viruses in such an event. For instance, it has been found that the HPV E6 and HPV E7 genes contribute to ESCC pathogenesis via DNA demethylation and upregulation of the human leukocyte antigen (HLA)-DQB1 [98]. Moreover, HPV-16 E6 downregulated microRNA (miR)- $125 \mathrm{~b}$ - a negative regulator of the $\mathrm{Wnt} / \beta$-catenin signaling pathway-thus contributing to EC carcinogenesis $[99,100]$. Besides the above-mentioned effects, HPV is likely involved in aberrations of the p53 protein and retinoblastoma pathway [101].

Some ESCC cases may arise as a combination of genetic susceptibility and HPV infection. Yang et al. managed to identify two risk loci, which were found to not only increase the risk for ESCC, but also interact with the HPV serological status [102]. Furthermore, in combination with HPV16 seropositivity, two p53 single nucleotide polymorphisms Arg/Arg and Arg/Pro increased the risk for ESCC [103]. Interestingly, HPV infection may not always worsen the prognosis of ESCC, as it has been found that HPV increased the tumor response to chemoradiation [104]. However, data are not clear regarding p53, as it was reported that HPV infection and p53 expression were not of any prognostic value [105]. Finally, HPV infection has been associated with telomere length. Zhang et al. reported that HPV-infected ESCC tumor tissue contained longer telomeres, due to the DNA methylation status of telomerase reverse transcriptase, compared with HPV-negative tissue [106].

Despite all of the data presented, two issues must be stressed. Firstly, most of the studies were observational (either prognostic or retrospective) and thus lack causality. Secondly, all of the studies were designed to detect the presence of either HPV or EBV in EC samples and, to the best of our knowledge, there is no study analyzing a complete virome panel in EC. Therefore, the answer to the question of whether viruses lead to a higher risk of EC may be even more complex than previously thought. 


\subsection{Gastric Cancer}

Data from epidemiological studies performed across the globe do not unambiguously unravel the potential role of HPV in the pathogenesis of gastric cancer (GC) $[107,108]$. Data on EBV and GC are also controversial. EBV is estimated to be widespread and studies carried out in the United Kingdom and United States reported an EBV seroprevalence higher than $90 \%$ in specific subgroups of people $[109,110]$. Despite that, EBV was found in only $9 \%$ of all GCs worldwide [111]. Similarly, the abundance of EBV was found to be very low in a Chinese population with GC incidence [112]. Yuan et al. did not detect any HPV or EBV DNA in GC tissue samples, whereas de Souza et al. found that only $20 \%$ of the tumors were positive for EBV and observed no expression of the HPV E6 and E7 oncogenic proteins $[113,114]$. In contrast, Martínez-López and co-workers revealed the presence of EBV in GC specimens and proposed that EBV may exert carcinogenic actions, either directly, by infecting epithelial cells, or indirectly, by inducing inflammation [47]. The variability of the above findings is further enhanced by the results of Corallo et al. [48]. The authors showed that EBV-positive metastatic GC patients, who did not receive immune checkpoint inhibitors, had a long-lasting and complete response to first-line chemotherapy, as well as better survival, compared to metastatic GC patients who were EBV-negative [48].

Recently, a number of studies have tried to shed light on the molecular mechanisms underlying the effects of EBV on GC pathogenesis. Zhang et al. [115] focused on the expression of the LMP2A protein, which is one of the proteins usually expressed by EBV in infected cells, and human epidermal growth factor receptor 2 (HER2), which is a protooncogen that has been associated with the development of different cancer types, such as esophageal [116], gastric [117], and breast [118] cancer. The overexpression of LMP2A in EBV-negative cells led to a decrease of HER2 mRNA. Interestingly, EBV-associated GC cases exhibited the highest survival when compared with cases bearing either low concentrations of LMP2A and HER2 or low concentrations of LMP2A and high concentrations of HER2 [115]. Along the same line is the study by Constanza Camargo et al., showing a higher rate of survival of EBV-positive GC patients compared with EBV-negative ones [119]. In contrast, the results published by Wang et al. seem to contradict the supposed beneficial effect of EBV in GC [120]. Besides proteins, EBV encodes many miRNAs and, among these, EBV-miR-BART3-3p was reported to promote the growth of GC cells, both in vitro and in vivo, by inhibiting their senescence induced by an oncogene (RASG12V) or chemotherapy (irinotecan) [120]. In conclusion, although EBV positivity seems to confer some sort of protection against GC, it is important to point out that the sole presence or absence of EBV in GC samples does not imply a direct causality or a role of EBV in this neoplasia. Epidemiological studies carried out in other countries and aimed at assessing whether EBV is latent or active in patients who develop GC would help clarify this issue.

\subsection{Liver Cancer}

In 2012, 770,000 cases of liver cancer occurred worldwide, of which 430,000 (56\%) and 150,000 $(20 \%)$ were attributed to hepatitis B virus (HBV) and hepatitis C virus (HCV), respectively [121]. Most of the liver cancer cases in the Western world are attributable to HCV, whereas HBV represents the major driver of liver carcinogenesis in developing countries [121]. The main non-viral risk factors for liver cancer are presumed to be alcohol consumption, tobacco smoking, diabetes, obesity, and aflatoxin B1 exposure in Africa and Eastern Asia [122]. The most common type of liver cancer is hepatocellular carcinoma (HCC), although in certain parts of the globe, such as South-Eastern Asia, intrahepatic bile duct cancer is the more frequent liver-associated neoplasia, due to the high presence of fluke infections [123]. Due to the huge amount of data on the proposed mechanisms by which $\mathrm{HBV}$ and $\mathrm{HCV}$ increase the risk of developing HCC, for detailed information on this topic, we refer the reader to other more specific reviews [124,125].

Although the above-mentioned viruses and factors account for the majority of HCC cases, other viruses, such as HPV and EBV, may play a role in liver carcinogenesis. So far, a very limited number of studies have focused on elucidating the potential role of HPV in HCC. A study dated to 1992 found HCC 
samples infected with either HPV-16 or HPV-18 and suggested that HPV could act synergistically with HBV to promote HCC development [126]. However, to the best of our knowledge, these results have not been replicated and more studies are needed to ascertain the possibility of such viral cooperation. Sugawara et al. detected EBV in one third of HCC samples [127], although subsequent studies did not confirm any involvement of EBV in the development of HCC [128-131]. Similarly, in a study from China, the authors found that more than $28 \%$ of HCC samples were EBV-positive and argued for a possible association between EBV and the genesis and development of HCC [49]. However, mechanistic studies demonstrating a clear cause-effect of the above-mentioned hypothesis are lacking. Song and colleagues associated the expression of the EBV-encoded gene 3 (EBI3), which has been found to be upregulated in a variety of cancers, e.g., lung [132], pancreatic [133], or cervical [134], with the outcome of HCC patients after curative resection [135]. A low expression of EBI3 was associated with recurrence of the disease and shorter survival [135]. Interestingly, this result is in line with data reporting a higher survival of GC patients who were EBV-positive, compared with EBV-negative ones [119]. Although the above-mentioned evidence would suggest that EBV confers some kind of protection to liver cancer patients, this is not true for all cases. Indeed, in a distinct subset of HCC characterized by an immune cell stroma, EBV-positive tumor-infiltrating leukocytes were associated with a worse prognosis [136].

The TT virus (TTV), first isolated in 1997 from a Japanese patient and named after his initials [137], is another virus suggested to play a role in HCC pathogenesis, although early studies from different countries did not report any association between either the presence of TTV and development of HCC $[138,139]$ or the severity or prognosis of TTV-positive versus -negative HCC patients [140]. In 2002, Tokita et al. indicated a high TTV load as an independent risk factor for HCC [55]. Conversely, in Egyptian patients, TTV was found to be abundant in, but not associated with, HBV, HCV, or HCC [141]. To date, the evidence produced does not seem to support an association between the presence of TTV and an increased risk of developing HCC. Further studies are needed in order to clarify this issue.

\subsection{Bile Duct Cancer}

Intrahepatic (IHCC) and extrahepatic cholangiocarcinoma (EHCC) represent the two most common forms of bile duct cancer [142]. There are a small number of studies investigating the relation between viruses and cholangiocarcinoma and mainly rely on an indirect approach, focused on the survival and prognosis of HBV- and/or HCV-infected patients. In this context, some potential mechanisms linking HCV and cholangiocarcinoma have been discussed by Navas et al. [143]. A study by Zhou et al. reported an odds ratio of 5.39 and 2.6 for HBV and HCV infection in IHCC, respectively [57]. Other studies are in agreement, stating that hepatitis viruses may be possible risk factors in the pathogenesis in cholangiocarcinoma [144-146]. A recent meta-analysis by Tan et al. concluded that both HBV and HCV infections significantly increase the risk of developing both IHCC and EHCC [147]. Nevertheless, some reports have failed to provide evidence linking HBV and HCV to bile duct carcinogenesis $[148,149]$. Studies analyzing the survival of cholangiocarcinoma patients with or without HBV infection are also not in agreement [150,151]. More recently, a study by Klufah and colleagues found a $59 \%$ prevalence of human polyomaviruses in cholangiocarcinoma patients [152]. The above results suggest the need for further investigations, in order to figure out the role of viruses in the pathogenesis of bile duct cancer.

\subsection{Pancreatic Cancer}

Based on the available literature, a limited number of viruses are supposedly involved in the development of pancreatic cancer (PC), with HBV and HCV as the most likely contributors. The available studies/meta-analyses do not clearly prove whether HBV and HCV infections are associated with a higher risk of developing PC. A meta-analysis by Wang et al. suggested that HBV infection may increase the risk of PC [153]. In contrast, Abe and co-workers found no association between HBV or HCV infection and PC [154]. Other papers have presented conflicting results. 
While no association has been reported in studies carried out in Southern China and Taiwan [155,156], a nationwide study from Sweden pointed towards a higher risk of PC in the HBV cohort [157]. However, it has to be pointed out that this latter observation did not reach statistical significance. In accordance with the Swedish study was the REVEAL-HBV cohort study by Iloeje et al. [56]. By investigating the presence of $\mathrm{HBV}$ in pancreatic tissue specimens, the authors suggested that chronic HBV infection could be associated with an increased risk of PC [56]. Research focusing on past HBV and HCV exposure is also contradictory. Indeed, some studies concluded that an association between past HBV infection and the risk of developing PC could be possible $[58,158]$, whereas Tang et al. reported no such an association [159]. Interestingly, in a study comparing the risk of HCC and PC development in HBV-infected individuals, the authors reported no increased risk for PC, but a 17-fold higher risk for HCC [160]. Research investigating the mechanism/s by which some viruses might increase the risk of PC is rather scarce. In a study performed on the pancreatic cancer cell lines PANC-1 and SW1990, a higher expression of receptor tyrosine kinase ErbB4 and TGF- $\alpha$ was found after HBV infection, along with the upregulation of MAPK and PI3K/AKT pathways [161]. To the best of our knowledge, no evidence advocates for a role of EBV in PC. In a study by Tomasiewicz et al., TT virus DNA was found in the sera of two patients who developed PC [162]. However, as we are not aware of any other report evaluating the association between TT virus and PC, it is impossible to draw any conclusion.

Taken together, despite certain advances that shed some light on the role of hepatitis viruses in the development of PC, more research is needed to uncover the putative molecular mechanisms governing the pancreatic carcinogenesis associated with viral infections.

\subsection{Colorectal Cancer}

Colorectal cancer (CRC), defined as a cancer arising in the human colon and/or rectum, is one of the most common and studied types of malignancy. In 2018, CRC was the third most frequently diagnosed cancer (with more than 1.8 million cases) and the second in terms of mortality, accounting for almost 900,000 deaths worldwide [66]. The human colon contains a vast viral load, comprising both viruses and phages. It is well-accepted that viruses help maintain proper functioning of the intestine [163] and that a shift of the composition and/or abundance of the intestinal virome far from the physiologic state may predispose to dysplasia and ultimately, cancer [164]. Although implications for viral engagement in the development of CRC are growing, current evidence is still relatively scarce. Given the sheer amount of living organisms and viruses in the colon, it is a great challenge to pinpoint the role of a single viral strain in the process of colon carcinogenesis. Therefore, it is not surprising that many studies have found associations which need to be further tested and verified.

\subsection{1. $\mathrm{HBV}$ and $\mathrm{HCV}$}

In contrast to their role in promoting liver carcinogenesis, hepatitis viruses (i.e., $\mathrm{HBV}$ and HCV) seem to decrease the risk of colorectal liver metastasis in CRC patients [165-167]. In line with this assumption, Li Destri and colleagues found better 5-year disease free survival and a lower incidence of metachronous liver metastases in hepatitis virus-infected CRC patients [168], whereas a subsequent study found no correlation between HCV prevalence and subjects symptomatic for CRC [169]. More recently, Su et al. suggested HBV infection to be significantly associated with an increased risk for CRC [59]. The results of this latter study oppose the putative protective effect of hepatitis virus infection against the development of liver metastases in CRC and highlight the need for additional research, in order to figure out such inconsistency.

\subsubsection{HPV}

The first association between HPV infection and CRC is dated to 1990, when, by immunohistochemistry and in situ hybridization, Kirgan and co-workers found that the HPV antigen was present in $60 \%$ of benign tumors and $97 \%$ of carcinomas, compared with $23 \%$ of normal colon specimens [41]. The authors also detected the HPV genome in $27 \%$ of benign tumors and in nearly 
$43 \%$ of all carcinomas tested. The same research group subsequently confirmed such findings by PCR and Southern blotting [170]. In another study, HPV-18 DNA was detected in 53\% of normal mucosal samples and $84 \%$ of CRC specimens [42]. Interestingly, Damin et al. found a similar abundance of another HPV strain (i.e., HPV-16) in CRC samples, whereas HPV-16 DNA was not detectable in the control group. However, no correlation between HPV presence and prognostic predictors could be observed [171]. Along the same lines is a study by Giuliani and colleagues, reporting the presence of HPV DNA in 22 out of 66 (33.3\%) CRC samples and indicating a possible association between HPV occurrence and an increased risk of developing CRC [172]. The possible contribution of HPV to CRC carcinogenesis was, however, questioned by other research articles which either did not find any presence [173] or only a low abundance [174,175] of HPV DNA in tumor specimens taken from CRC patients. Moreover, it has even been suggested that HPV-positivity might be caused by contamination from the anal canal or during sample processing [174]. Despite having identified only six out of 140 total CRC samples as HPV-positive compared to no positive samples in the control group, Mahmoudvand et al. still proposed a potential role for HPV in CRC carcinogenesis [176].

Several studies have attempted to uncover the mechanisms underlying the possible link between HPV infection and CRC. In this regard, Qiu et al. performed a gene expression analysis and found four upregulated and differentially expressed genes in HPV-positive CRC samples compared to HPV-negative tissues [177]. These genes coded proteins, namely WNT-5A, c-Myc, matrix metalloproteinase 7 (MMP-7), and AXIN2, which have been previously implicated in CRC pathogenesis [177]. For instance, the WNT-5A protein is a member of the WNT gene family, which is involved in key cellular processes, such as differentiation, proliferation, and migration via $\mathrm{Wnt} / \beta$-catenin signalization [178]. In theory, once inserted into the genome of the cell, certain viruses such as HPV can interact with the Wnt pathway to promote the transcription of genes involved in proliferation (Figure 1).

In a similar fashion, c-Myc acts as a protooncogene which has been shown to be constitutively expressed, besides CRC [179], in other cancer types, such as breast cancer [180] and lung cancer [181,182]. MMP-7 has been associated with colorectal tumor growth and metastasis and one meta-analysis found that its overexpression could even serve as a prognostic factor [183]. Likewise, AXIN2 has been associated with CRC [184].

Another study reported a correlation between HPV infection and worse clinical stages of CRC [185]. Notably, HPV infection also correlated with higher activity of the transcription factor STAT3 and a higher expression of the pro-inflammatory cytokine interleukin-17 [185], both of which have been shown to be involved in CRC carcinogenesis [32]. The ability to evade or suppress programmed cell death is one of the hallmarks of cancer cells [186]. In this context, Karbasi et al. found a significantly lower expression of the pro-apoptotic genes FAS and DR5 in HPV-positive CRC samples compared to normal tissue [187]. Other signaling pathways, such as the MAPK/ERK pathway, may be involved, as Buyru et al. observed that $56 \%$ of HPV-positive CRC samples carried mutations in the protooncogene $K$-Ras [188]. Although it remains inconclusive, research has also been conducted to determine a possible association between HPV infection and p53 mutation [189,190].

Taken together, despite a considerable amount of data pointing toward the notion of a carcinogenic effect of HPV infection, more studies are needed to elucidate whether such infection arises before, during, or after CRC development and whether the aforementioned changes in gene expression are strictly dependent on HPV, rather than driven by other factors.

\subsubsection{EBV}

Studies concerning the association of EBV with CRC are limited. One of the first reports on the potential carcinogenic effect of EBV comes from Song and colleagues, who detected the presence of EBV in almost $80 \%$ of CRC specimens [50]. Next, Fiorina et al. reported the presence of EBV DNA in more than half of the CRC tumor samples [51]. However, due to the huge variability in the amount of EBV DNA detected, the authors concluded that EBV was not significantly involved in CRC [51]. A later 
study by Sarvari and co-workers seemed to sustain this conclusion, as the authors could only detect EBV in 1 out of 70 tumor specimens taken from Iranian CRC patients [191]. It needs, however, to be pointed out that, as the prevalence of EBV infection varies considerably worldwide, the scope of such population studies may be limited. As a result, the absence of EBV infection may not necessarily mean that EBV does not cause or increase the risk for CRC development. Recently, Malki and colleagues investigated the role of HPV-EBV co-infection in CRC [192]. Indeed, whilst each of these viruses does not seem to present an immediate threat when acting alone, they could pose a much greater challenge to the colon when occurring together. HPV-EBV co-infection was reported in $17 \%$ of the samples and associated with invasive carcinoma features [192]. However, another study by the same group partially contradicted this conclusion, as no significant association between the co-presence of high-risk HPV and EBV and clinicopathological variables was found [193]. Finally, Liang et al. investigated the potential effect of EBV-Induced Gene 3 (EBI3) on the tumor microenvironment. An increase in EBI3 was detected in human CRC specimens and associated with phosphorylated STAT3. The administration of an EBI3 blocking peptide led to an antitumor cytotoxic T lymphocyte response and the inhibition of CRC cell proliferation in a tumor xenograft model [194]. In conclusion, although certain data may indicate an indirect role of EBV in CRC, any evidence beyond a possible association has not yet been proven.

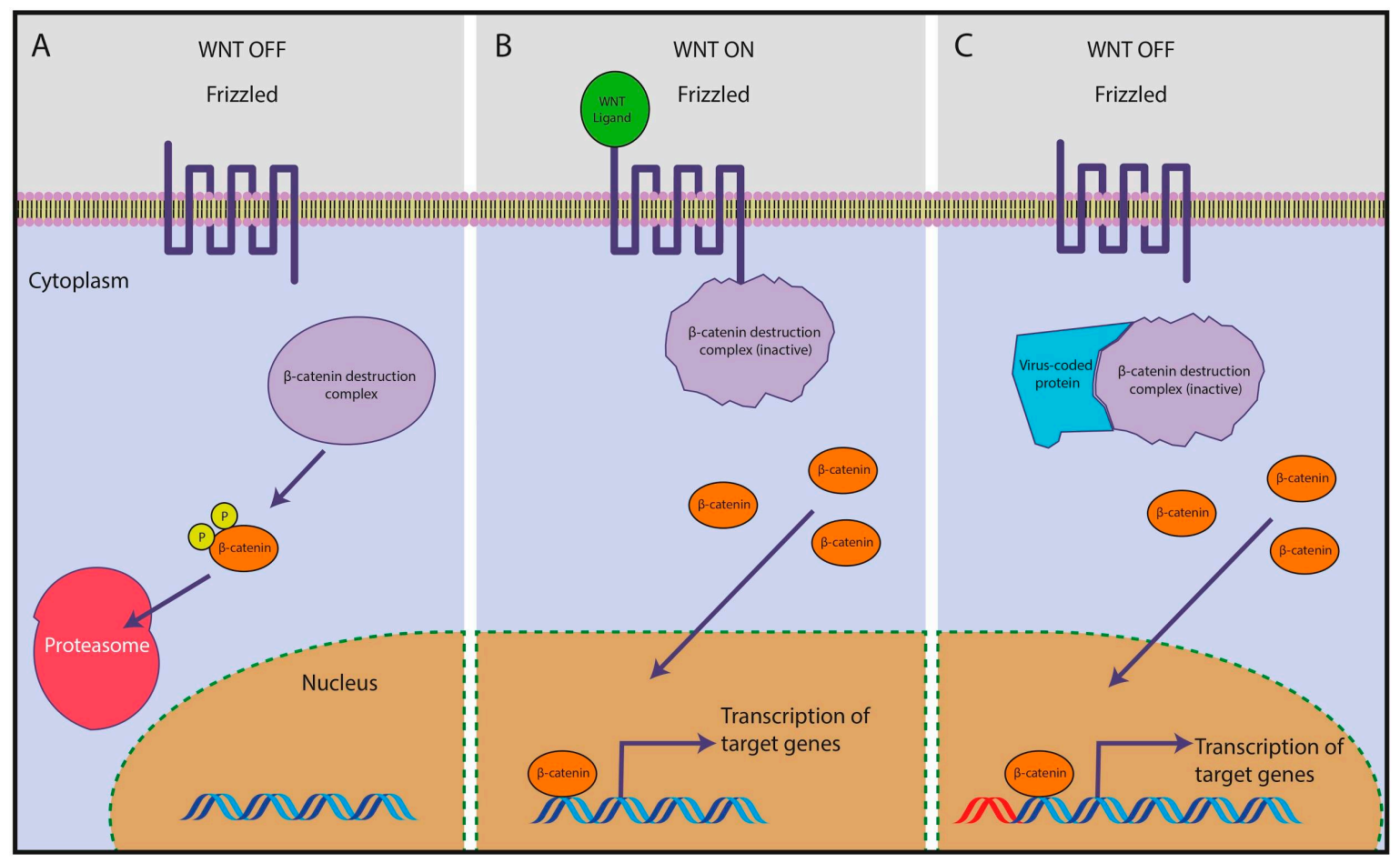

Figure 1. Virus-mediated modulation of the Wnt/ $\beta$-catenin pathway. (A) When Wnt signalization is off, $\beta$-catenin is phosphorylated via the $\beta$-catenin destruction complex and subsequently degraded by the proteasome. (B) When a Wnt ligand binds a Wnt receptor (Frizzled), the $\beta$-catenin destruction complex is inactive, and $\beta$-catenin accumulates and enters the nucleus, where it modulates the transcription of target genes. $(C)$ When infecting a cell, a virus may interact with some of the Wnt pathway components (e.g., the $\beta$-catenin destruction complex), leading to the accumulation of $\beta$-catenin and persistent transcription of its target genes, even in the absence of a Wnt ligand.

\subsubsection{Cytomegalovirus}

Another potentially important player in CRC carcinogenesis may be human CMV, which belongs to the Herpesviridae family of viruses. CMV has been shown to preferentially infect CRC lesions compared to normal healthy tissue $[60,195,196]$. Interestingly, a difference in CMV positivity was observed between Vietnamese and Swedish patients, with the former being significantly more 
infected by CMV [60]. The prevalence of CMV infection in a given population seems to depend on the geographical location. Further studies supporting this assumption are, however, necessary. Chen and colleagues revealed that the presence of CMV in CRC tumors was associated with a worse outcome and an increased expression of interleukin-17 in elder patients [197], whereas a more favorable disease-free survival rate was reported in CMV-positive non-elderly (aged $<65$ years) CRC patients, suggesting that there may be a possible age-dependent effect [61]. However, other studies argued against the involvement of CMV in CRC carcinogenesis [198,199].

Multiple mechanisms have been proposed to contribute to the potential carcinogenic effect of CMV in CRC. For instance, it seems that genetic polymorphisms in the CMV genome may affect the outcome of CRC. Specifically, Chen et al. detected the presence of CMV in $47.8 \%$ of the CRC specimens analyzed. Among these, three different polymorphisms of the viral immunomodulatory gene UL144 (termed genotype A, B, and C) were identified. The presence of genotype B, occurring in $30.2 \%$ of the CMV-positive samples and characterized by the highest UL144 expression, was associated with shorter disease-free survival and independently predicted tumor recurrence [62]. Other discoveries came from studying the association between CMV and the expression of TLRs. In CMV-infected CRC and adenoma samples, the levels of expression of TLR2, TLR4, NF- $\mathrm{KB}$, and TNF- $\alpha$ were higher compared to control tissues. These results were partially confirmed in the CRC cell line SW480, where only levels of TLR2 and TNF- $\alpha$ were increased [200]. In Caco-2 cells, CMV infection induced the expression of Bcl-2 and cyclooxygenase-2 (cox-2), which are two proteins involved in CRC carcinogenesis [201,202]. Interestingly, a study by Teo et al. showed that CMV infection promoted migration of the CRC cell lines HT29 and SW480. Mechanistically, this effect was associated with a six-fold upregulation of the Wnt/ $\beta$-catenin signaling pathway compared to the non-infected cells [203]. Cai and co-workers investigated the role of the CMV-encoded US28 gene, coding one of the four G protein-coupled receptors believed to be essential for viral latent infection [204], in CRC pathogenesis [205]. The authors found a higher level of the US28 gene in CRC samples compared to adjacent normal tissue. Higher amounts of US28 were associated with histological grade, metastasis, Dukes' stage, and survival [205]. In this context, US28-mediated activation of the Wnt $/ \beta$-catenin pathway in CMV-infected cells has already been observed by Langemeijer and colleagues [206]. In addition, it has been shown that CMV may promote angiogenesis and carcinogenesis via the action of US28 and cox-2 [207]. Taken together, the available evidence strongly suggests that CMV may be able to interact with the mechanisms involved in CRC cell proliferation and progression. However, whether CMV can cause cell transformation by itself or should be viewed as a factor contributing to CRC development remains to be elucidated.

\subsubsection{John Cunningham Virus}

Human polyomavirus 2, more commonly known as John Cunningham virus (JCV), which is a member of Polyomaviruses named after a patient with progressive multifocal leukoencephalopathy from whom it was isolated [208], has also been studied in relation to CRC [209]. In 1999, Laghi and colleagues firstly identified JCV in CRC colonic mucosa and suggested a possible link between the occurrence of JCV and CRC [52]. Since then, a number of studies have attempted to assess the prevalence of and, more recently, the association between, JCV and CRC. The majority of such studies point towards a possible carcinogenic role of JCV [53,54,210,211]. However, some reports did not find any significant difference between the presence or absence of JCV in CRC samples and thus concluded that the effect of JCV on CRC carcinogenesis either needed further validation or was non-existent [212-215].

JCV has been proposed to promote colon carcinogenesis in a number of ways. Firstly, a possible link between the expression of T-antigen (T-ag) - an early JCV protein which is believed to mediate the oncogenic potential of the virus-and chromosomal instability has been found [216,217]. In this regard, the hypermethylation of hMLH1 was associated with tumor JCV positivity and this suggested that the virus was capable of inducing aberrant methylation, as well as chromosomal instability [218]. 
Although the higher incidence of T-ag in patients with a family history of CRC did not correlate with mutations in DNA repair genes [219], these observations merit additional research. Secondly, JCV may be responsible for the induction of polymorphisms and/or alterations in tumor suppressor genes, such as p53 [220] (Figure 2), as well as for prioritizing for infection those cells which carry defects in tumor suppressor genes. This assumption is supported by the fact that $\mathrm{p} 53$ has been shown to inhibit JCV DNA replication via interacting with the T-ag. The highly conserved central region of p53 is responsible for such inhibition and this means that mutations in this region may affect the protection conferred by p53 [221]. Thirdly, JCV may alter cell behavior. After infecting with JCV the CRC cell lines HCT116 and SW837, cells expressing T-ag showed a two- to three-fold increase in migration and invasion compared to controls. Treatment with inhibitors of PI3K/AKT and MAPK pathways reduced both cell migration and invasion, thus underlining a possible involvement of such pathways in the JCV-driven increase of CRC metastasis [222]. Evidence supporting the involvement of JCV in the $\mathrm{Wnt} / \beta$-catenin signaling cascade is even stronger. Enam et al. found that the coproduction of the viral T-ag and $\beta$-catenin in colon cancer cells enhanced the transcription of the oncogenic factor c-Myc [223]. Subsequently, the expression of TCF-4, which is a component of Wnt $/ \beta$-catenin signaling, has been reported to decrease JCV DNA replication [224]. In this way, JCV may be able to interact with and modulate the Wnt pathway in colonic cells via the T-ag. These results were further confirmed by Ripple and colleagues, who found that the simultaneous presence of T-ag and $\beta$-catenin led to the activation of cell cycle regulators (i.e., c-Myc and cyclin D1) [225]. In another study, JCV was associated with p53, cyclin D1, and a family history of CRC, but neither with microsatellite instability nor changes in $\beta$-catenin and cox-2 expression [226].

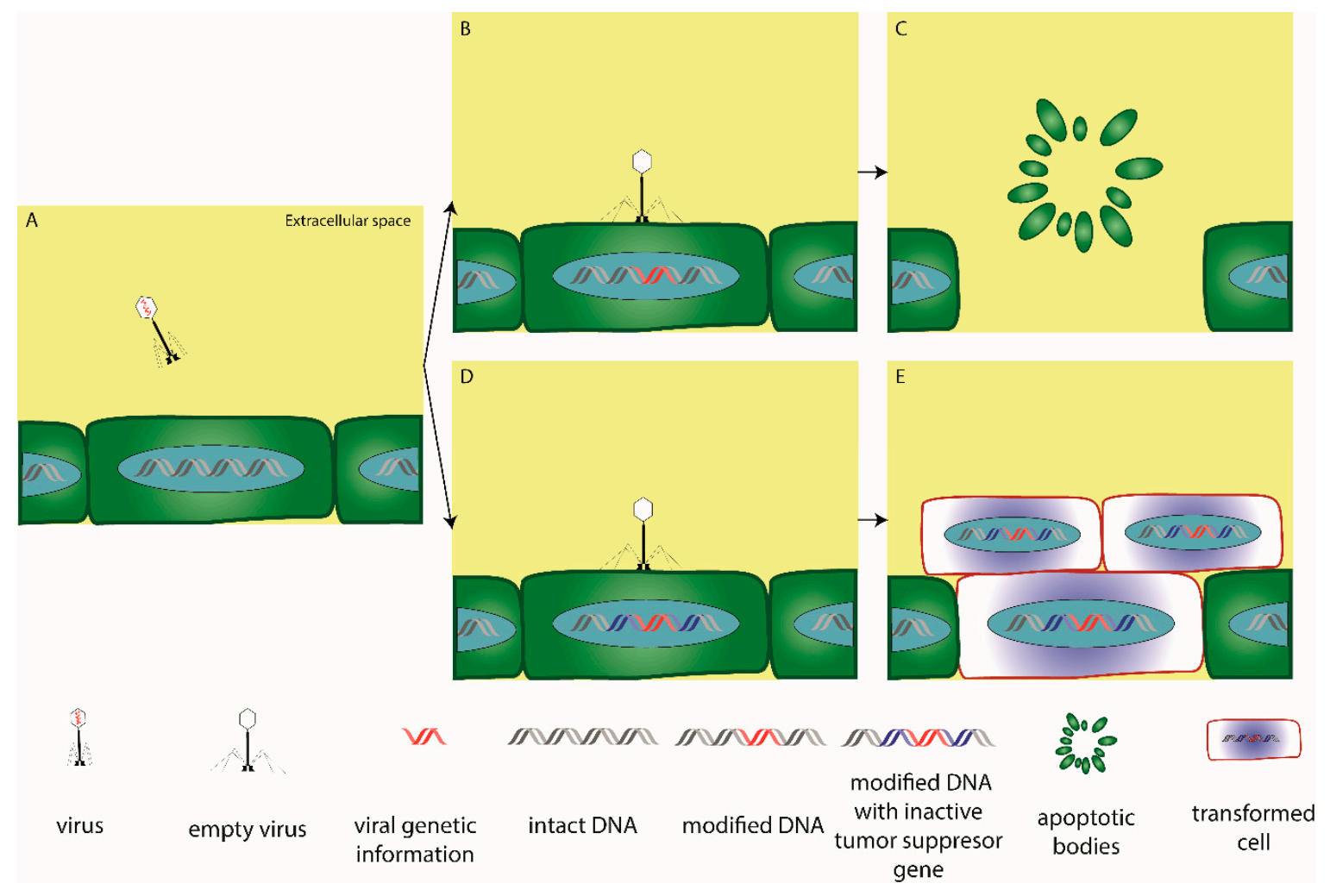

Figure 2. Example of virus-mediated carcinogenesis. A virus can infect a eukaryotic cell (A) and randomly insert its genetic information into the host genome via the lysogenic life cycle (B,D). If the viral genetic material falls in a non-coding region, the modified host DNA continues to function normally until the cell reaches senescence and is removed by apoptosis (C). However, the integration of the viral genome into a region coding a tumor suppressor gene (such as p53 or Rb), can affect cell proliferation/survival and, in combination with other DNA modifications, contribute to uncontrollable cell division, which may result in dysplasia and eventually, cancer (E). 
While the body of evidence strongly supports a role for JCV in contributing to CRC carcinogenesis, future studies should be aimed at investigating the conditions under which such cell signaling regulation can happen.

\subsection{Anal Cancer}

While colon and rectal cancers share similar features and are often referred to collectively as CRC, anal cancer (AC) differs in significant ways, including the tissue where neoplastic transformation begins (similar to that lining the woman's cervix), pathogenesis, and treatment [227]. Although AC is an uncommon tumor, accounting for about $2 \%$ of gastrointestinal malignancies, its frequency is increasing, especially in high-risk groups [228]. The predominant type of tumor (corresponding to $80 \%$ of all cases) is squamous cell carcinoma, which shares many features with cervical cancer [227]. Given the affinities with this latter tumor and the well-accepted role of HPV in cervical cancer pathogenesis, it is not surprising that the available evidence suggests a major role for this virus (in particular, the HPV-16) in the development of AC. In this regard, there are even estimates stating that HPV may be the underlying cause for as many as $90 \%$ of all AC cases [229]. Studies from different countries have reported the presence of HPV DNA in more than half of the AC specimens analyzed. For instance, Alexandrou et al. detected HPV DNA in 54.5\% of tumor samples taken from Greek AC patients [43]. A Brazilian study reported an even higher HPV prevalence (69\%), although it needs to be noted that HPV did not influence patient survival [230]. Using the United States National Cancer Database registry, Kabarriti et al. showed that $59.4 \%$ of non-metastatic AC patients treated with curative intent between 2008 and 2014 had HPV-positive disease [44]. Patients with an early stage of disease did not show significant differences in overall survival when stratified for HPV positivity. Surprisingly, in patients with HPV-positive advanced AC, the overall survival was better compared to HPV-negative patients with an equal disease stage [44]. In a recent observational, retrospective study carried out in North Sardinia, Italy, Muresu et al. assessed the prevalence and distribution of HPV genotypes in patients diagnosed with AC [45]. The overall HPV positivity was 70\%, with HPV-16 being the predominant genotype (approximately 85\%). The authors also found overexpression of the tumor suppressor protein p16 ${ }^{\text {INK4a }}$, which is a surrogate marker for HPV infection that appears to have prognostic value in AC [231]. Despite this, the authors did not report any statistically significant difference in the overall survival between HPV-positive and -negative individuals, probably due to study limitations related to both sample size and epidemiological variables [45]. In contrast to this latter finding, when $\mathrm{p} 16^{\mathrm{INK} 4 a}$ was expressed in HPV-positive AC patients, better overall survival was observed [232,233] and at the same time, HPV-negative patients without p16 expression had a worse outcome [234]. Of particular importance is a study by Małusecka et al., who measured the HPV-16 viral load and expression of p $16^{\mathrm{INK} 4 \mathrm{a}}$ and p53 in AC patients. The authors described an inverse trend in the association between the viral load and $\mathrm{p} 16^{\mathrm{INK} 4 \mathrm{a}}$ expression status [235]. In addition to studies on human AC samples, HPV mouse models of anal carcinogenesis have been employed. For instance, one research group found that HPV-driven anal carcinogenesis can be modulated via autophagy. Their results showed that the systemic and topical administration of BEZ235, which is a PI3K/mTOR inhibitor, caused lower anal carcinogenesis via autophagy activation [236,237]. In 2018, Wechsler et al. firstly established an HPV-16 immortalized anal epithelial cell line (i.e., AKC2), which expressed the HPV genes E5, E6, and E7 [238]. These HPV genes have been associated with AC [238-240]. Upon a reduction of the E5 expression via short interfering RNA, lower amounts of both total and phosphorylated epidermal growth factor receptors were observed, along with reduced invasion. At the same time, the expression of E6 and E7 remained unaffected, thus supporting the role of E5 in the development of AC [238].

Apart from acting alone, HPV may cooperate with human immunodeficiency virus (HIV) to increase the probability of AC development. This is not surprising, as HIV patients bear a weakened immune system and thus have a higher chance of developing malignancies compared to the general population [241]. Studies have found a higher prevalence of AC in HIV patients [63], mainly in men who have sex with men $[64,242]$. In addition, Grew et al. observed significantly worse overall 
and colostomy-free survival rates in HIV-positive AC patients compared to HIV-negative ones [65]. Wentzensen et al. analyzed various biomarkers, such as HPV DNA, p16, and E6/E7 mRNA, in relation to AC severity in HIV-infected men who had sex with men. An increase in the above-mentioned biomarkers correlated with an increased severity of the disease, with HPV DNA having the highest sensitivity for anal intraepithelial dysplasia of grade 2 and 3 [243]. Another study suggested a possibility for HPV-16 E6 serology, despite its low sensitivity, to characterize a group of individuals with a very high anal cancer incidence and predict AC risk [244]. Bertisch and colleagues reported that, apart from HPV E6, the HPV L1 gene and smoking were significantly associated with AC [245]. Even though a study dated to 2013 showed that the recurrence rate of AC was associated with HIV positivity, but not with HPV/p16 [246], Liu and colleagues recently reported an association between HPV-16 positivity and the presence of high-grade lesions in AC patients [247]. In conclusion, accumulating evidence indicates that HPV infection, either alone or concomitant with HIV infection, likely contributes to the development of AC.

\section{Discussion and Future Outlooks}

The study of microbial entities that may be involved in the development of malignancies of the alimentary tract has mainly concentrated on the bacterial component of the microbiome [2]. Another large, but less studied, portion of the digestive system microbiome is that consisting of both bacteriophages and viruses (infecting prokaryotic and eukaryotic cells, respectively), together known as the virome [3]. Despite the recent advent of cutting-edge technologies in nucleic acid sequencing, omics analysis, and bioinformatics pipelines, characterization of the gut virome and its role in the development of pathological conditions has been slowed by several hurdles and is still in the early stages.

Most of the studies described herein have focused on the prevalence of infection with a certain virus in a type of cancer in a given geographical location. While data gathered in such a manner can be undoubtedly seen as a necessary first step, it is important to point out that such studies do not carry the collective knowledge beyond the level of association and may be hampered by methodological flaws. Indeed, research on patients usually contains many potentially confounding factors (e.g., age, sex, environment, geography, lifestyle and sexual habits, and simultaneous comorbidities) that may reasonably impact the structure and function of the virome in the short or long term. The use of related individuals living in the same household/environment, rather than unrelated randomly selected individuals, may be useful for reducing such a bias. Another concern relates to cross-study comparisons of datasets, which are almost impossible due to differences in sample collection, handling, storage, and processing (e.g., isolation of viral-like particles, DNA/RNA extraction, sequencing platforms, and parameters). The development of standardized protocols, as well as the establishment of Gold Standard procedures, would help address this issue. Finally, as the virome composition may differ from early to late stages of disease, research in this area should take into account a rigorous analysis of tumor stadiation. Discovering molecular mechanisms behind virus-cell communication may be of particular importance in the future. To elucidate the potential carcinogenic role of a given virus, functional studies involving cell cultures and animal models should be employed to a greater extent. However, determining the functional impact of a virus as a cancer agent requires effective vaccines or antivirals. If eliminating the infection also eliminates the cancer, then the link is clear. Unfortunately, such an approach requires specific drug and vaccine development, which only occurs once a virus is already established to cause a disease or cancer, and there is sufficient economic interest on the part of biopharmaceutical companies. In 2018, about 2.2 million cancer cases, or $13 \%$ of the global cancer incidence, were attributable to infection (and in particular, to viruses) [248]. In accordance with this assumption, a number of cancers of the digestive system have either been proven or are believed to come from a relatively small number of viral strains (i.e., $\mathrm{HBV}, \mathrm{HCV}$, and $\mathrm{HPV}$ ). This means that a fraction of such cancers could be, in theory, preventable by vaccination. As preventive vaccines for HBV and HPV are fortunately available, it should be one of the priorities of governments to educate 
people and provide measures (i.e., HBV and HPV prophylaxis), in order to minimize the carcinogenic impact of such viral infections and subsequently lower the cancer burden on the healthcare system.

A sector of the virome that remains inadequately investigated is the phageome. This is particularly true for the colon, which harbors conditions such as a mild $\mathrm{pH}$ and nutrient-rich environment, allowing for the abundant occurrence of bacteria and thus phages. Although research in the field has made great strides, whether phages play a role in the development of gastrointestinal cancer remains an unanswered question. To date, publications considering the possibility that phages may be a driving force of carcinogenesis in the gut are lacking [249]. Certain phages could theoretically act as mediators of carcinogenesis, for example, due to endowing bacteria with genes by horizontal gene transfer. Conversely, other phages may provide a protective effect, preying on those bacteria with increased invasion and fitness [20]. One of key tasks of future virome investigations should be to elucidate which phages and circumstances could tip the balance towards either a carcinogenic or anti-carcinogenic effect.

While some of the potential virome-mediated carcinogenic effects occurring in the gut can be induced by a direct interaction of viruses with the host cells, others may require the interplay of viruses with other components of the microbiome (commensal bacteria, archaea, fungi, and protozoans, among other organisms). The above-mentioned interactions may take place regardless of whether the enteric viruses replicate locally in the intestine or whether they use the gut as a point of entry to the host, showing their pathologic effects in organs other than the gastrointestinal tract [30]. To help unravel these complex connections, future gut virome research should be complemented by that on gut bacterial and fungal diversity.

Notwithstanding, it is important to point out that viral infections are generally not sufficient for cancer development, as cancers are evolutionarily dead-end events that threaten the viral agent as much as the host. Indeed, viral-mediated tumors only occur in a minor fraction of infected individuals when additional events (e.g., immune system suppression and exposure to carcinogens) and/or concomitant host factors (e.g., genetic predisposition and somatic mutations) exist.

\section{Conclusions}

Despite the recent increase of the awareness about the relationship between specific viruses (i.e., HBV, HCV, EBV, and JCV) and the pathogenesis of oral, hepatic, colorectal, and anal cancers, the human virome remains largely uncharacterized and we still have a poor knowledge on how it may influence the risk of developing cancers of the digestive system. Further mechanistic studies using experimental models and multicenter observational cohort studies-designed to pay attention to the potential biases-would hopefully help with further unravelling such a complex topic.

Author Contributions: Conceptualization, literature search, and writing-original draft preparation, M.M.; graphical editing, R.L.; funding acquisition, review, and editing, R.G. and G.M.; conceptualization, writing-review, and editing, C.S. All authors have read and agreed to the published version of the manuscript.

Funding: This work was supported by the Slovak Research and Development Agency under the contract no. APVV-17-0505.

Conflicts of Interest: The authors declare no conflict of interest.

\section{References}

1. Gillings, M.R.; Paulsen, I.T.; Tetu, S.G. Ecology and evolution of the human microbiota: Fire, farming and antibiotics. Genes 2015, 6, 841-857. [CrossRef] [PubMed]

2. Wang, B.; Yao, M.; Lv, L.; Ling, Z.; Li, L. The Human Microbiota in Health and Disease. Engineering 2017, 3 , 71-82. [CrossRef]

3. Columpsi, P.; Sacchi, P.; Zuccaro, V.; Cima, S.; Sarda, C.; Mariani, M.; Gori, A.; Bruno, R. Beyond the gut bacterial microbiota: The gut virome. J. Med. Virol. 2016, 88, 1467-1472. [CrossRef] 
4. Gregory, A.C.; Zablocki, O.; Zayed, A.A.; Howell, A.; Bolduc, B.; Sullivan, M.B. The Gut Virome Database Reveals Age-Dependent Patterns of Virome Diversity in the Human Gut. Cell Host Microbe 2020. [CrossRef] [PubMed]

5. Minot, S.; Sinha, R.; Chen, J.; Li, H.; Keilbaugh, S.A.; Wu, G.D.; Lewis, J.D.; Bushman, F.D. The human gut virome: Inter-individual variation and dynamic response to diet. Genome Res. 2011, 21, 1616-1625. [CrossRef] [PubMed]

6. Hoyles, L.; McCartney, A.L.; Neve, H.; Gibson, G.R.; Sanderson, J.D.; Heller, K.J.; van Sinderen, D. Characterization of virus-like particles associated with the human faecal and caecal microbiota. Res. Microbiol. 2014, 165, 803-812. [CrossRef] [PubMed]

7. Castro-Mejía, J.L.; Muhammed, M.K.; Kot, W.; Neve, H.; Franz, C.M.A.P.; Hansen, L.H.; Vogensen, F.K.; Nielsen, D.S. Optimizing protocols for extraction of bacteriophages prior to metagenomic analyses of phage communities in the human gut. Microbiome 2015, 3, 64. [CrossRef]

8. Neil, J.A.; Cadwell, K. The Intestinal Virome and Immunity. J. Immunol. 2018, 201, 1615-1624. [CrossRef] [PubMed]

9. Koonin, E.V.; Dolja, V.V.; Krupovic, M. Origins and evolution of viruses of eukaryotes: The ultimate modularity. Virology 2015, 479-480, 2-25. [CrossRef] [PubMed]

10. Norman, J.M.; Handley, S.A.; Virgin, H.W. Kingdom-agnostic metagenomics and the importance of complete characterization of enteric microbial communities. Gastroenterology 2014, 146, 1459-1469. [CrossRef]

11. Kernbauer, E.; Ding, Y.; Cadwell, K. An enteric virus can replace the beneficial function of commensal bacteria. Nature 2014, 516, 94-98. [CrossRef]

12. Yang, J.Y.; Kim, M.S.; Kim, E.; Cheon, J.H.; Lee, Y.S.; Kim, Y.; Lee, S.H.; Seo, S.U.; Shin, S.H.; Choi, S.S.; et al. Enteric Viruses Ameliorate Gut Inflammation via Toll-like Receptor 3 and Toll-like Receptor 7-Mediated Interferon- $\beta$ Production. Immunity 2016, 44, 889-900. [CrossRef] [PubMed]

13. Krump, N.A.; You, J. Molecular mechanisms of viral oncogenesis in humans. Nat. Rev. Microbiol. 2018, 16, 684-698. [CrossRef]

14. Galtier, M.; De Sordi, L.; Sivignon, A.; de Vallée, A.; Maura, D.; Neut, C.; Rahmouni, O.; Wannerberger, K.; Darfeuille-Michaud, A.; Desreumaux, P.; et al. Bacteriophages targeting adherent invasive Escherichia coli strains as a promising new treatment for Crohn's disease. J. Crohn's Colitis 2017, 11, 840-847. [CrossRef] [PubMed]

15. Zuo, T.; Lu, X.-J.; Zhang, Y.; Cheung, C.P.; Lam, S.; Zhang, F.; Tang, W.; Ching, J.Y.L.; Zhao, R.; Chan, P.K.S.; et al. Gut mucosal virome alterations in ulcerative colitis. Gut 2019, 68, 1169-1179. [CrossRef]

16. Emlet, C.; Ruffin, M.; Lamendella, R. Enteric Virome and Carcinogenesis in the Gut. Dig. Dis. Sci. 2020, 65, 852-864. [CrossRef]

17. Gethings-Behncke, C.; Coleman, H.G.; Jordao, H.W.T.; Longley, D.B.; Crawford, N.; Murray, L.J.; Kunzmann, A.T. Fusobacterium nucleatum in the colorectum and its association with cancer risk and survival: A systematic review and meta-analysis. Cancer Epidemiol. Biomark. Prev. 2020, 29, 539-548. [CrossRef]

18. Gogokhia, L.; Buhrke, K.; Bell, R.; Hoffman, B.; Brown, D.G.; Hanke-Gogokhia, C.; Ajami, N.J.; Wong, M.C.; Ghazaryan, A.; Valentine, J.F.; et al. Expansion of Bacteriophages Is Linked to Aggravated Intestinal Inflammation and Colitis. Cell Host Microbe 2019, 25, 285-299.e8. [CrossRef]

19. Brüssow, H.; Canchaya, C.; Hardt, W.-D. Phages and the Evolution of Bacterial Pathogens: From Genomic Rearrangements to Lysogenic Conversion. Microbiol. Mol. Biol. Rev. 2004, 68, 560-602. [CrossRef] [PubMed]

20. Maronek, M.; Link, R.; Ambro, L.; Gardlik, R. Phages and Their Role in Gastrointestinal Disease: Focus on Inflammatory Bowel Disease. Cells 2020, 18, 1013. [CrossRef]

21. Brown-Jaque, M.; Rodriguez Oyarzun, L.; Cornejo-Sánchez, T.; Martín-Gómez, M.T.; Gartner, S.; de Gracia, J.; Rovira, S.; Alvarez, A.; Jofre, J.; González-López, J.J.; et al. Detection of Bacteriophage Particles Containing Antibiotic Resistance Genes in the Sputum of Cystic Fibrosis Patients. Front. Microbiol. 2018, 9, 856. [CrossRef] [PubMed]

22. Mirold, S.; Rabsch, W.; Rohde, M.; Stender, S.; Tschape, H.; Russmann, H.; Igwe, E.; Hardt, W.-D. Isolation of a temperate bacteriophage encoding the type III effector protein SopE from an epidemic Salmonella typhimurium strain. Proc. Natl. Acad. Sci. USA 1999, 96, 9845-9850. [CrossRef]

23. Goh, S.; Chang, B.J.; Riley, T.V. Effect of phage infection on toxin production by Clostridium difficile. J. Med. Microbiol. 2005, 54, 129-135. [CrossRef] [PubMed] 
24. Eriksson, F.; Culp, W.D.; Massey, R.; Egevad, L.; Garland, D.; Persson, M.A.A.; Pisa, P. Tumor specific phage particles promote tumor regression in a mouse melanoma model. Cancer Immunol. Immunother. 2007, 56, 677-687. [CrossRef] [PubMed]

25. Eriksson, F.; Tsagozis, P.; Lundberg, K.; Parsa, R.; Mangsbo, S.M.; Persson, M.A.A.; Harris, R.A.; Pisa, P. Tumor-Specific Bacteriophages Induce Tumor Destruction through Activation of Tumor-Associated Macrophages. J. Immunol. 2009, 182, 3105-3111. [CrossRef]

26. Rampoldi, A.; Crooke, S.N.; Preininger, M.K.; Jha, R.; Maxwell, J.; Ding, L.; Spearman, P.; Finn, M.G.; Xu, C. Targeted Elimination of Tumorigenic Human Pluripotent Stem Cells Using Suicide-Inducing Virus-like Particles. ACS Chem. Biol. 2018, 13, 2329-2338. [CrossRef] [PubMed]

27. Dabrowska, K.; Opolski, A.; Wietrzyk, J.; Switala-Jelen, K.; Boratynski, J.; Nasulewicz, A.; Lipinska, L.; Chybicka, A.; Kujawa, M.; Zabel, M.; et al. Antitumor activity of bacteriophages in murine experimental cancer models caused possibly by inhibition of $\beta 3$ integrin signaling pathway. Acta Virol. 2004, 48, 241-248.

28. Dąbrowska, K.; Opolski, A.; Wietrzyk, J.; Nevozhay, D.; Szczaurska, K.; Świtała-Jeleń, K.; Boratyński, J.; Górski, A. Activity of bacteriophages in murine tumor models depends on the route of phage administration. Oncol. Res. 2005, 15, 183-187.

29. Shan, J.; Ramachandran, A.; Thanki, A.M.; Vukusic, F.B.I.; Barylski, J.; Clokie, M.R.J. Bacteriophages are more virulent to bacteria with human cells than they are in bacterial culture; Insights from HT-29 cells. Sci. Rep. 2018, 8, 5091. [CrossRef]

30. Zárate, S.; Taboada, B.; Yocupicio-Monroy, M.; Arias, C.F. Human Virome. Arch. Med. Res. 2017, 48, 701-716. [CrossRef]

31. Landskron, G.; De La Fuente, M.; Thuwajit, P.; Thuwajit, C.; Hermoso, M.A. Chronic inflammation and cytokines in the tumor microenvironment. J. Immunol. Res. 2014, 2014, 149185. [CrossRef] [PubMed]

32. De Simone, V.; Franzè, E.; Ronchetti, G.; Colantoni, A.; Fantini, M.C.; Di Fusco, D.; Sica, G.S.; Sileri, P.; MacDonald, T.T.; Pallone, F.; et al. Th17-type cytokines, IL- 6 and TNF- $\alpha$ synergistically activate STAT3 and NF-kB to promote colorectal cancer cell growth. Oncogene 2015, 34, 3493-3503. [CrossRef]

33. Morales-Sánchez, A.; Fuentes-Pananá, E.M. Human viruses and cancer. Viruses 2014, 6, 4047-4079. [CrossRef] [PubMed]

34. Muller, M.; Broséus, J.; Feugier, P.; Thieblemont, C.; Laurent, B.; Danese, S.; Arnone, D.; Ndiaye, N.C.; Kokten, T.; Houlgatte, R.; et al. Characteristics Of Lymphoma In Patients With Inflammatory Bowel Disease: A Systematic Review. J. Crohn's Colitis 2020. [CrossRef]

35. Pal, A.; Kundu, R. Human Papillomavirus E6 and E7: The Cervical Cancer Hallmarks and Targets for Therapy. Front. Microbiol. 2020, 10, 3116. [CrossRef] [PubMed]

36. Maden, C.; Beckmann, A.M.; Thomas, D.B.; Mcknight, B.; Sherman, K.J.; Ashley, R.L.; Corey, L.; Daling, J.R. Human papillomaviruses, herpes simplex viruses, and the risk of oral cancer in men. Am. J. Epidemiol. 1992, 135, 1093-1102. [CrossRef]

37. Jalouli, J.; Jalouli, M.M.; Sapkota, D.; Ibrahim, S.O.; Larsson, P.A.; Sand, L. Human papilloma virus, herpes simplex virus and epstein barr virus in oral squamous cell carcinoma from eight different countries. Anticancer Res. 2012, 32, 571-580.

38. Bjørge, T.; Hakulinen, T.; Engeland, A.; Jellum, E.; Koskela, P.; Lehtinen, M.; Luostarinen, T.; Paavonen, J.; Sapp, M.; Schiller, J.; et al. A prospective, seroepidemiological study of the role of human papillomavirus in esophageal cancer in norway. Cancer Res. 1997, 57, 3989-3992.

39. Zhang, S.; Guo, L.; Chen, Q.; Zhang, M.; Liu, S.; Quan, P.; Lu, J. The association between human papillomavirus 16 and esophageal cancer in Chinese population: A meta-analysis. BMC Cancer 2015, 15, 99. [CrossRef]

40. Wang, X.; Tian, X.; Liu, F.; Zhao, Y.; Sun, M.; Chen, D.; Lu, C.; Wang, Z.; Shi, X.; Zhang, Q.; et al. Detection of HPV DNA in esophageal cancer specimens from different regions and ethnic groups: A descriptive study. BMC Cancer 2010, 10, 19. [CrossRef]

41. Kirgan, D.; Manalo, P.; Hall, M.; Mcgregor, B. Association of Human Papillomavirus and Colon Neoplasms. Arch. Surg. 1990, 125, 862-865. [CrossRef] [PubMed]

42. Lee, Y.; Leu, S.; Chiang, H.; Fung, C.; Liu, W. Human Papillomavirus Type 18 in Colorectal Cancer. J. Microbiol. Immunol. Infect. 2001, 34, 87-91. [PubMed]

43. Alexandrou, A.; Dimitriou, N.; Levidou, G.; Griniatsos, J.; Sougioultzis, S.; Korkolopoulou, P.; Felekouras, E.; Pikoulis, E.; Diamantis, T.; Tsigris, C.; et al. The Incidence of HPV Infection in Anal Cancer Patients in Greece. Acta Gastroenterol. Belg. 2014, 77, 213-216. [PubMed] 
44. Kabarriti, R.; Brodin, N.P.; Ohri, N.; Narang, R.; Huang, R.; Chuy, J.W.; Rajdev, L.N.; Kalnicki, S.; Guha, C.; Garg, M.K. Human papillomavirus, radiation dose and survival of patients with anal cancer. Acta Oncol. (Madr.) 2019, 58, 1745-1751. [CrossRef]

45. Muresu, N.; Sotgiu, G.; Saderi, L.; Sechi, I.; Cossu, A.; Marras, V.; Meloni, M.; Martinelli, M.; Cocuzza, C.; Tanda, F.; et al. Distribution of hpv genotypes in patients with a diagnosis of anal cancer in an Italian region. Int. J. Environ. Res. Public Health 2020, 17, 4516. [CrossRef] [PubMed]

46. Awerkiew, S.; Bollschweiler, E.; Metzger, R.; Schneider, P.M.; Hölscher, A.H.; Pfister, H. Esophageal cancer in germany is associated with Epstein-Barr-virus but not with papillomaviruses. Med. Microbiol. Immunol. 2003, 192, 137-140. [CrossRef] [PubMed]

47. Martínez-López, J.L.E.; Torres, J.; Camorlinga-Ponce, M.; Mantilla, A.; Leal, Y.A.; Fuentes-Pananá, E.M. Evidence of Epstein-Barr virus association with gastric cancer and non-atrophic gastritis. Viruses 2014, 6, 301-318. [CrossRef]

48. Corallo, S.; Fucà, G.; Morano, F.; Salati, M.; Spallanzani, A.; Gloghini, A.; Volpi, C.C.; Trupia, D.V.; Lobefaro, R.; Guarini, V.; et al. Clinical Behavior and Treatment Response of Epstein-Barr Virus-Positive Metastatic Gastric Cancer: Implications for the Development of Future Trials. Oncologist 2020, 25, 780-786. [CrossRef]

49. Li, W.; Wu, B.A.; Zeng, Y.M.; Chen, G.C.; Li, X.X.; Chen, J.T.; Guo, Y.W.; Li, M.H.; Zeng, Y. Epstein-Barr virus in hepatocellular carcinogenesis. World J. Gastroenterol. 2004, 10, 3409-3413. [CrossRef]

50. Song, L.-B.; Zhang, X.; Zhang, C.-Q.; Zhang, Y.; Pan, Z.-Z.; Liao, W.-T.; Li, M.-Z.; Zeng, M.-S. Infection of Epstein-Barr Virus in Colorectal Cancer in Chinese. Chin. J. Cancer 2006, 25, 1356-1360.

51. Fiorina, L.; Ricotti, M.; Vanoli, A.; Luinetti, O.; Dallera, E.; Riboni, R.; Paolucci, S.; Brugnatelli, S.; Paulli, M.; Pedrazzoli, P.; et al. Systematic analysis of human oncogenic viruses in colon cancer revealed EBV latency in lymphoid infiltrates. Infect. Agent. Cancer 2014, 9, 18. [CrossRef]

52. Laghi, L.; Randolph, A.E.; Chauhan, D.P.; Marra, G.; Major, E.O.; Neel, J.V.; Boland, C.R. JC virus DNA is present in the mucosa of the human colon and in colorectal cancers. Proc. Natl. Acad. Sci. USA 1999, 96, 7484-7489. [CrossRef] [PubMed]

53. Hori, R.; Murai, Y.; Tsuneyama, K.; Abdel-Aziz, H.O.; Nomoto, K.; Takahashi, H.; Cheng, C.M.; Kuchina, T.; Harman, B.V.; Takano, Y. Detection of JC virus DNA sequences in colorectal cancers in Japan. Virchows Arch. 2005, 447, 723-730. [CrossRef]

54. Jung, W.T.; Li, M.S.; Goel, A.; Boland, C.R. JC virus T-antigen expression in sporadic adenomatous polyps of the colon. Cancer 2008, 112, 1028-1036. [CrossRef] [PubMed]

55. Tokita, H.; Murai, S.; Kamitsukasa, H.; Yagura, M.; Harada, H.; Takahashi, M.; Okamoto, H. High TT virus load as an independent factor associated with the occurrence of hepatocellular carcinoma among patients with hepatitis C virus-related chronic liver disease. J. Med. Virol. 2002, 67, 501-509. [CrossRef]

56. Iloeje, U.H.; Yang, H.I.; Jen, C.L.; Su, J.; Wang, L.Y.; You, S.L.; Lu, S.N.; Chen, C.J. Risk of pancreatic cancer in chronic hepatitis B virus infection: Data from the REVEAL-HBV cohort study. Liver Int. 2010, 30, 423-429. [CrossRef] [PubMed]

57. Zhou, Y.; Zhao, Y.; Li, B.; Huang, J.; Wu, L.; Xu, D.; Yang, J.; He, J. Hepatitis viruses infection and risk of intrahepatic cholangiocarcinoma: Evidence from a meta-analysis. BMC Cancer 2012, 12, 289. [CrossRef]

58. Hassan, M.M.; Li, D.; El-Deeb, A.S.; Wolff, R.A.; Bondy, M.L.; Davila, M.; Abbruzzese, J.L. Association between hepatitis B virus and pancreatic cancer. J. Clin. Oncol. 2008, 26, 4557-4562. [CrossRef]

59. Su, F.H.; Le, T.N.; Muo, C.H.; Te, S.A.; Sung, F.C.; Yeh, C.C. Chronic hepatitis B virus infection associated with increased colorectal cancer risk in Taiwanese population. Viruses 2020, 12, 97. [CrossRef]

60. Dimberg, J.; Hong, T.; Skarstedt, M.; Löfgren, S.; Zar, N.; Matussek, A. Detection of Cytomegalovirus DNA in Colorectal Tissue From Swedish and Vietnamese Patients With Colorectal Cancer. Anticancer Res. 2013, 33, $4947-4950$.

61. Chen, H.P.; Jiang, J.K.; Chen, C.Y.; Yang, C.Y.; Chen, Y.C.; Lin, C.H.; Chou, T.Y.; Cho, W.L.; Chan, Y.J. Identification of human cytomegalovirus in tumour tissues of colorectal cancer and its association with the outcome of non-elderly patients. J. Gen. Virol. 2016, 97, 2411-2420. [CrossRef]

62. Chen, H.P.; Jiang, J.K.; Chan, C.H.; Teo, W.H.; Yang, C.Y.; Chen, Y.C.; Chou, T.Y.; Lin, C.H.; Chan, Y.J. Genetic polymorphisms of the human cytomegalovirus UL144 gene in colorectal cancer and its association with clinical outcome. J. Gen. Virol. 2015, 96, 3613-3623. [CrossRef] 
63. Jin, F.; Vajdic, C.M.; Law, M.; Amin, J.; Van Leeuwen, M.; McGregor, S.; Poynten, I.M.; Templeton, D.J.; Grulich, A.E. Incidence and time trends of anal cancer among people living with HIV in Australia. AIDS 2019, 33, 1361-1368. [CrossRef] [PubMed]

64. Colón-López, V.; Shiels, M.S.; Machin, M.; Ortiz, A.P.; Strickler, H.; Castle, P.E.; Pfeiffer, R.M.; Engels, E.A. Anal cancer risk among people with HIV infection in the United States. J. Clin. Oncol. 2018, 36, 68-75. [CrossRef] [PubMed]

65. Grew, D.; Bitterman, D.; Leichman, C.G.; Leichman, L.; Sanfilippo, N.; Moore, H.G.; Du, K. HIV infection is associated with poor outcomes for patients with anal cancer in the highly active antiretroviral therapy era. Dis. Colon Rectum 2015, 58, 1130-1136. [CrossRef] [PubMed]

66. Ferlay, J.; Colombet, M.; Soerjomataram, I.; Mathers, C.; Parkin, D.M.; Piñeros, M.; Znaor, A.; Bray, F. Estimating the global cancer incidence and mortality in 2018: GLOBOCAN sources and methods. Int. J. Cancer 2019, 144, 1941-1953. [CrossRef]

67. Gupta, B.; Johnson, N.W. Systematic review and meta-analysis of association of smokeless tobacco and of betel quid without tobacco with incidence of oral cancer in south asia and the pacific. PLoS ONE 2014, 9, e113385. [CrossRef]

68. Conway, D.I.; Purkayastha, M.; Chestnutt, I.G. The changing epidemiology of oral cancer: Definitions, trends, and risk factors. Br. Dent. J. 2018, 225, 867. [CrossRef]

69. Sand, L.; Jalouli, J. Viruses and oral cancer. Is there a link? Microbes Infect. 2014, 16, 371-378. [CrossRef]

70. Kouvousi, M.; Xesfyngi, D.; Tsimplaki, E.; Argyri, E.; Ioannidou, G.; Ploxorou, M.; Lazaris, A.; Patsouris, E.; Panotopoulou, E. Prevalence of human papillomavirus in 45 greek patients with oral cancer. J. Oncol. 2013, 2013, 756510. [CrossRef]

71. González-Ramírez, I.; Irigoyen-Camacho, M.E.; Ramírez-Amador, V.; Lizano-Soberón, M.; Carrillo-García, A.; García-Carrancá, A.; Sánchez-Pérez, Y.; Méndez-Martínez, R.; Granados-García, M.; Ruíz-Godoy, L.M.; et al. Association between age and high-risk human papilloma virus in Mexican oral cancer patients. Oral Dis. 2013, 19, 796-804. [CrossRef]

72. Chaitanya, N.; Allam, N.; Gandhi Babu, D.; Waghray, S.; Badam, R.; Lavanya, R. Systematic meta-analysis on association of human papilloma virus and oral cancer. J. Cancer Res. Ther. 2016, 12, 969-974. [CrossRef] [PubMed]

73. Kane, S.; Patil, V.M.; Noronha, V.; Joshi, A.; Dhumal, S.; D'Cruz, A.; Bhattacharjee, A.; Prabhash, K. Predictivity of human papillomavirus positivity in advanced oral cancer. Indian J. Cancer 2015, 52, 403-405.

74. Sritippho, T.; Pongsiriwet, S.; Lertprasertsuke, N.; Buddhachat, K.; Sastraruji, T.; Iamaroon, A. p16-A Possible Surrogate Marker for High-Risk Human Papillomaviruses in Oral Cancer? Asian Pac. J. Cancer Prev. 2016, 17, 4049-4057.

75. Chiba, I.; Shindoh, M.; Yasuda, M.; Yamazaki, Y.; Amemiya, A.; Sato, Y.; Fujinaga, K.; Notani, K.; Fukuda, H. Mutations in the 53 gene and human papillomavirus infection as significant prognostic factors in squamous cell carcinomas of the oral cavity. Oncogene 1996, 12, 1663-1668. [PubMed]

76. Cutilli, T.; Leocata, P.; Dolo, V.; Altobelli, E. Association between p53 status, human papillomavirus infection, and overall survival in advanced oral cancer after resection and combination systemic treatment. Br. J. Oral Maxillofac. Surg. 2016, 54, 198-202. [CrossRef]

77. Mundi, N.; Prokopec, S.D.; Ghasemi, F.; Warner, A.; Patel, K.; MacNeil, D.; Howlett, C.; Stecho, W.; Plantinga, P.; Pinto, N.; et al. Genomic and human papillomavirus profiling of an oral cancer cohort identifies TP53 as a predictor of overall survival. Cancers Head Neck 2019, 4, 5. [CrossRef] [PubMed]

78. Rustgi, A.K.; El-Serag, H.B. Esophageal carcinoma. N. Engl. J. Med. 2014, 371, 2499-2509. [CrossRef]

79. Syrjänen, K.; Pyrhönen, S.; Aukee, S.; Koskela, E. Squamous cell papilloma of the esophagus: A tumour probably caused by human papilloma virus (HPV). Diagn. Histopathol. 1982, 5, 291-296.

80. Lagergren, J.; Wang, Z.; Bergstro, R.; Dillner, J.; Nyre, O. Human Papillomavirus Infection and Esophageal Cancer: A Nationwide Seroepidemiologic Case-Control Study in Sweden. J. Natl. Cancer Inst. 1999, 91, 156-162. [CrossRef]

81. Dąbrowski, A.; Kwaśniewski, W.; Skoczylas, T.; Bednarek, W.; Kuźma, D.; Goździcka-józefiak, A. Incidence of human papilloma virus in esophageal squamous cell carcinoma in patients from the Lublin region. World J. Gastroenterol. WJG 2012, 18, 5739-5744. 
82. Li, T.; Lu, Z.; Chen, K.; Guo, M.; Xing, H.; Mei, Q.; Yang, H.; Lechner, J.F.; Ke, Y. Human papillomavirus type 16 is an important infectious factor in the high incidence of esophageal cancer in Anyang area of China (HPV) infection in the pathogenesis of esophageal carcin-. Carcinogenesis 2001, 22, 929-934. [CrossRef] [PubMed]

83. Mohammadpour, B.; Rouhi, S.; Khodabandehloo, M. Prevalence and Association of Human Papillomavirus with Esophageal Squamous Cell Carcinoma in Iran: A Systematic Review and Meta-Analysis. Iran. J. Public Health 2019, 48, 1215-1226.

84. Baş, Y.; Aker, V.; Aylin, G. Effect of high-risk human papillomavirus in esophageal squamous cell carcinoma in Somalian and Turkish cases. Pathog. Dis. 2019, 77, ftz047. [CrossRef]

85. Castillo, A.; Aguayo, F.; Koriyama, C.; Torres, M.; Carrascal, E.; Corvalan, A.; Roblero, J.P.; Naquira, C.; Palma, M.; Backhouse, C.; et al. Human papillomavirus in esophageal squamous cell carcinoma in Colombia and Chile. World J Gastroenterol. WJG 2006, 12, 6188-6192. [CrossRef]

86. Da Costa, A.; Fregnani, J.; Pastrez, P.; Mariano, V.; Neto, C.; Guimarães, D.; de Oliveira, K.; Neto, S.; Nunes, E.; Ferreira, S.; et al. Prevalence of high risk HPV DNA in esophagus is high in Brazil but not related to esophageal squamous cell carcinoma. Histol. Histopathol. 2018, 33, 357-363.

87. Koshiol, J.; Kreimer, A.R. Lessons from Australia: HPV is not a major risk factor foresophageal squamous cell carcinoma. Cancer Epidemiol. Biomark. Prev. 2010, 19, 1889-1892. [CrossRef]

88. Antunes, L.; Prolla, J.C.; Lopes, A.D.B.; Pires, M.; Carlos, L.; Antunes, M.; Prolla, J.C. No evidence of HPV DNA in esophageal squamous cell carcinoma in a population of Southern Brazil. World J. Gastroenterol. 2013, 19, 6598-6603. [CrossRef]

89. Antonsson, A.; Nancarrow, D.J.; Brown, I.S.; Green, A.C.; Drew, P.A.; Watson, D.I.; Hayward, N.K.; Whiteman, D.C. High-risk human papillomavirus in esophageal squamous cell carcinoma. Cancer Epidemiol. Biomark. Prev. 2010, 19, 2080-2087. [CrossRef]

90. Chang, F.; Syrjänen, S.; Shen, Q.; Cintorino, M.; Santopietro, R.; Tosi, P.; Syrjänen, K. Evaluation of HPV, CMV, HSV and EBV in Esophageal Squamous Cell Carcinomas From a High-Incidence Area of China. Anticancer Res. 2000, 20, 3935-3940.

91. Xi, R.; Zhang, X.; Chen, X.; Pan, S.; Hui, B.; Zhang, L.; Fu, S.; Li, X.; Zhang, X.; Gong, T.; et al. Human papillomavirus 16 infection predicts poor outcome in patients with esophageal squamous cell carcinoma. OncoTargets Ther. 2015, 8, 573-581. [CrossRef]

92. Wang, L.S.; Chow, K.C.; Wu, Y.C.; Li, W.Y.; Huang, M.H. Detection of Epstein-Barr virus in esophageal squamous cell carcinoma in Taiwan. Am. J. Gastroenterol. 1999, 94, 2834-2839. [CrossRef] [PubMed]

93. Hong, T.; Shimada, Y.; Kano, M.; Kaganoi, J.; Uchida, S.; Komoto, I.; Yamabe, H.; Imamura, M. The Epstein-Barr virus is rarely associated with esophageal cancer. Int. J. Mol. Med. 2000, 5, 363-368. [CrossRef]

94. Yanai, H.; Hirano, A.; Matsusaki, K.; Kawano, T.; Miura, O.; Yoshida, T.; Okita, K.; Shimizu, N. Epstein-Barr Virus Association Is Rare in Esophageal Squamous Cell Carcinoma. Int. J. Gastrointest. Cancer 2003, 33, 165-170. [CrossRef]

95. Awerkiew, S.; Zur Hausen, A.; Baldus, S.E.; Hölscher, A.H.; Sidorenko, S.I.; Kutsev, S.I.; Pfister, H.J. Presence of Epstein-Barr virus in esophageal cancer is restricted to tumor infiltrating lymphocytes. Med. Microbiol. Immunol. 2005, 194, 187-191. [CrossRef]

96. Sarbia, M.; Zur Hausen, A.; Feith, M.; Geddert, H.; Von Rahden, B.H.A.; Langer, R.; Von Weyhern, C.; Siewert, J.R.; Höfler, H.; Stein, H.J. Esophageal (Barrett's) adenocarcinoma is not associated with Epstein-Barr virus infection: An analysis of 162 cases. Int. J. Cancer 2005, 117, 698-700. [CrossRef]

97. Sunpaweravong, S.; Mitarnun, W.; Puttawibul, P. Absence of Epstein-Barr virus in esophageal squamous cell carcinoma. Dis. Esophagus 2005, 18, 398-399. [CrossRef] [PubMed]

98. Feng, B.; Awuti, I.; Deng, Y.; Li, D.; Niyazi, M.; Aniwar, J.; Sheyhidin, I.; Lu, G.; Li, G.; Zhang, L. Human papillomavirus promotes esophageal squamous cell carcinoma by regulating DNA methylation and expression of HLA-DQB1. Asia. Pac. J. Clin. Oncol. 2014, 10, 66-74. [CrossRef] [PubMed]

99. Zang, B.; Huang, G.; Wang, X.; Zheng, S. HPV-16 E6 promotes cell growth of esophageal cancer via downregulation of miR-125b and activation of $\mathrm{Wnt} / \beta$-catenin signaling pathway. Int. J. Clin. Exp. Pathol. 2015, 8, 13687-13694.

100. Rampias, T.; Boutati, E.; Pectasides, E.; Sasaki, C.; Kountourakis, P.; Weinberger, P.; Psyrri, A. Activation of Wnt signaling pathway by human papillomavirus E6 and E7 oncogenes in HPV16-positive oropharyngeal squamous carcinoma cells. Mol. Cancer Res. 2010, 8, 433-443. [CrossRef] 
101. Rajendra, S.; Yang, T.; Xuan, W.; Sharma, P.; Pavey, D.; Lee, C.S.; Le, S.; Collins, J.; Wang, B. Active human papillomavirus involvement in Barrett's dysplasia and oesophageal adenocarcinoma is characterized by wild-type p53 and aberrations of the retinoblastoma protein pathway. Int. J. Cancer 2017, 141, 2037-2049. [CrossRef]

102. Yang, J.; Wu, H.; Wei, S.; Xiong, H.; Fu, X.; Qi, Z.; Jiang, Q.; Li, W.; Hu, G.; Yuan, X.; et al. HPV seropositivity joints with susceptibility loci identified in GWASs at apoptosis associated genes to increase the risk of Esophageal Squamous Cell Carcinoma (ESCC). BMC Cancer 2014, 14, 501. [CrossRef] [PubMed]

103. Yang, J.; Liu, B.; Li, W.; Xiong, H.; Qiu, H.; Fu, Q.; Chen, B.; Hu, G.; Yuan, X. Association of p53 and MDM2 polymorphisms with risk of human papillomavirus (HPV)-related esophageal squamous cell carcinoma (ESCC). Cancer Epidemiol. 2013, 37, 629-633. [CrossRef] [PubMed]

104. Zhang, D.; Zhang, W.; Liu, W.; Mao, Y.; Fu, Z.; Liu, J.; Huang, W.; Zhang, Z.; An, D.; Li, B. Human papillomavirus infection increases the chemoradiation response of esophageal squamous cell carcinoma based on P53 mutation. Radiother. Oncol. 2017, 124, 155-160. [CrossRef] [PubMed]

105. Da Costa, A.M.; Fregnani, J.H.T.G.; Pastrez, P.R.A.; Mariano, V.S.; Silva, E.M.; Neto, C.S.; Guimarães, D.P.; Villa, L.L.; Sichero, L.; Syrjanen, K.J.; et al. HPV infection and p53 and p16 expression in esophageal cancer: Are they prognostic factors? Infect. Agent. Cancer 2017, 12, 54. [CrossRef]

106. Zhang, D.H.; Chen, J.Y.; Hong, C.Q.; Yi, D.Q.; Wang, F.; Cui, W. High-risk human papillomavirus infection associated with telomere elongation in patients with esophageal squamous cell carcinoma with poor prognosis. Cancer 2014, 120, 2673-2683. [CrossRef]

107. Snietura, M.; Waniczek, D.; Piglowski, W.; Kopec, A.; Nowakowska-Zajdel, E.; Lorenc, Z.; Muc-Wierzgon, M. Potential role of human papilloma virus in the pathogenesis of gastric cancer. World J. Gastroenterol. 2014, 20, 6632-6637. [CrossRef]

108. Zeng, Z.-M.; Luo, F.-F.; Zou, L.-X.; He, R.-Q.; Pan, D.-H.; Chen, X.; Xie, T.-T.; Li, Y.-Q.; Peng, Z.-G.; Chen, G. Human papillomavirus as a potential risk factor for gastric cancer: A meta-analysis of 1917 cases. OncoTargets Ther. 2016, 9, 7105-7114. [CrossRef]

109. Pembrey, L.; Raynor, P.; Griffiths, P.; Chaytor, S.; Wright, J.; Hall, A.J. Seroprevalence of cytomegalovirus, Epstein Barr virus and varicella zoster virus among pregnant women in Bradford: A cohort study. PLoS ONE 2013, 8, e81881. [CrossRef]

110. Dowd, J.B.; Palermo, T.; Brite, J.; McDade, T.W.; Aiello, A. Seroprevalence of Epstein-Barr Virus Infection in U.S. Children Ages 6-19, 2003-2010. PLoS ONE 2013, 8, e64921. [CrossRef]

111. Rodriquenz, M.G.; Roviello, G.; D'Angelo, A.; Lavacchi, D.; Roviello, F.; Polom, K. MSI and EBV Positive Gastric Cancer's Subgroups and Their Link With Novel Immunotherapy. J. Clin. Med. 2020, 9, 1427. [CrossRef]

112. Aversa, J.G.; Song, M.; Hu, N.; Goldstein, A.M.; Hewitt, S.M.; Gulley, M.L.; Dawsey, S.; Camargo, M.C.; Taylor, P.R.; Rabkin, C.S. Low epstein-barr virus prevalence in cardia gastric cancer among a high-incidence Chinese population. Dig. Dis. Sci. 2020. [CrossRef]

113. Yuan, X.Y.; Wang, M.Y.; Wang, X.Y.; Chang, A.Y.; Li, J. Non-detection of Epstein-Barr virus and Human Papillomavirus in a region of high gastric cancer risk indicates a lack of a role for these viruses in gastric carcinomas. Genet. Mol. Biol. 2013, 36, 183-184. [CrossRef]

114. De Souza, C.R.T.; Almeida, M.C.A.; Khayat, A.S.; Da Silva, E.L.; Soares, P.C.; Chaves, L.C.; Burbano, R.M.R. Association between Helicobacter pylori, Epstein-Barr virus, human papillomavirus and gastric adenocarcinomas. World J. Gastroenterol. 2018, 24, 4928-4938. [CrossRef]

115. Zhang, Y.W.; Zhao, X.X.; Tan, C.; Zhang, Z.G.; Jiang, Y.; Chen, J.N.; Wei, H.B.; Xue, L.; Li, H.G.; Du, H.; et al. Epstein-Barr virus latent membrane protein 2A suppresses the expression of HER2 via a pathway involving TWIST and YB-1 in Epstein-Barr virus-associated gastric carcinomas. Oncotarget 2015, 6, 207-220. [CrossRef]

116. Yoon, H.H.; Shi, Q.; Sukov, W.R.; Wiktor, A.E.; Khan, M.; Sattler, C.A.; Grothey, A.; Wu, T.T.; Diasio, R.B.; Jenkins, R.B.; et al. Association of HER2/ErbB2 expression and gene amplification with pathologic features and prognosis in esophageal adenocarcinomas. Clin. Cancer Res. 2012, 18, 546-554. [CrossRef]

117. Hofmann, M.; Stoss, O.; Shi, D.; Büttner, R.; Van De Vijver, M.; Kim, W.; Ochiai, A.; Rüschoff, J.; Henkel, T. Assessment of a HER2 scoring system for gastric cancer: Results from a validation study. Histopathology 2008, 52, 797-805. [CrossRef]

118. Kreutzfeldt, J.; Rozeboom, B.; Dey, N.; De, P. The Trastuzumab Era: Current and Upcoming Targeted HER2+ Breast Cancer Therapies. Am. J. Cancer Res. 2020, 10, 1045-1067. 
119. Constanza Camargo, M.; Kim, W.H.; Chiaravalli, A.M.; Kim, K.M.; Corvalan, A.H.; Matsuo, K.; Yu, J.; Sung, J.J.Y.; Herrera-Goepfert, R.; Meneses-Gonzalez, F.; et al. Improved survival of gastric cancer with tumour Epstein-Barr virus positivity: An international pooled analysis. Gut 2014, 63, 236-243. [CrossRef]

120. Wang, J.; Zheng, X.; Qin, Z.; Wei, L.; Lu, Y.; Peng, Q.; Gao, Y.; Zhang, X.; Zhang, X.; Li, Z.; et al. Epstein-Barr virus miR-BART3-3p promotes tumorigenesis by regulating the senescence pathway in gastric cancer. J. Biol. Chem. 2019, 294, 4854-4866. [CrossRef]

121. Maucort-Boulch, D.; de Martel, C.; Franceschi, S.; Plummer, M. Fraction and incidence of liver cancer attributable to hepatitis B and C viruses worldwide. Int. J. Cancer 2018, 142, 2471-2477. [CrossRef]

122. Bosetti, C.; Turati, F.; La Vecchia, C. Hepatocellular carcinoma epidemiology. Best Pract. Res. Clin. Gastroenterol. 2014, 28, 753-770. [CrossRef]

123. Xia, J.; Jiang, S.C.; Peng, H.J. Association between liver fluke infection and hepatobiliary pathological changes: A systematic review and meta-analysis. PLoS ONE 2015, 10, e0132673. [CrossRef]

124. Arzumanyan, A.; Reis, H.M.G.P.V.; Feitelson, M.A. Pathogenic mechanisms in HBV- and HCV-associated hepatocellular carcinoma. Nat. Rev. Cancer 2013, 13, 123-135. [CrossRef] [PubMed]

125. Zemel, R.; Issachar, A.; Tur-Kaspa, R. The Role of Oncogenic Viruses in the Pathogenesis of Hepatocellular Carcinoma. Clin. Liver Dis. 2011, 15, 261-279. [CrossRef]

126. Scinicariello, F.; Sato, T.; Lee, C.S.; Hsu, H.C.; Chan, T.S.; Tyring, S.K. Detection of human papillomavirus in primary hepatocellular carcinoma. Anticancer Res. 1992, 12, 763-766.

127. Sugawara, Y.; Makuuchi, M.; Takada, K. Detection of Epstein-Barr virus DNA in hepatocellular carcinoma tissues from hepatitis C-positive patients. Scand. J. Gastroenterol. 2000, 35, 981-984.

128. Chu, P.G.; Chen, Y.Y.; Chen, W.G.; Weiss, L.M. No direct role for epstein-barr virus in American hepatocellular carcinoma. Am. J. Pathol. 2001, 159, 1287-1292. [CrossRef]

129. Akhter, S.; Liu, H.; Prabhu, R.; DeLucca, C.; Bastian, F.; Garry, R.F.; Schwartz, M.; Thung, S.N.; Dash, S. Epstein-Barr virus and human hepatocellular carcinoma. Cancer Lett. 2003, 192, 49-57. [CrossRef]

130. Junying, J.; Herrmann, K.; Davies, G.; Lissauer, D.; Bell, A.; Timms, J.; Reynolds, G.M.; Hubscher, S.G.; Young, L.S.; Niedobitek, G.; et al. Absence of Epstein-Barr virus DNA in the tumor cells of European hepatocellular carcinoma. Virology 2003, 306, 236-243. [CrossRef]

131. Zur Hausen, A.; van Beek, J.; Bloemena, E.; ten Kate, F.J.; Meijer, C.J.L.M.; van den Brule, A.J.C. No role for Epstein-Barr virus in Dutch hepatocellular carcinoma: A study at the DNA, RNA and protein levels. J. Gen. Virol. 2003, 84, 1863-1869. [CrossRef] [PubMed]

132. Nishino, R.; Takano, A.; Oshita, H.; Ishikawa, N.; Akiyama, H.; Ito, H.; Nakayama, H.; Miyagi, Y.; Tsuchiya, E.; Kohno, N.; et al. Identification of Epstein-Barr virus-induced gene 3 as a novel serum and tissue biomarker and a therapeutic target for lung cancer. Clin. Cancer Res. 2011, 17, 6272-6286. [CrossRef] [PubMed]

133. Michaud, D.; Mirlekar, B.; Bischoff, S.; Cowley, D.O.; Vignali, D.A.A.; Pylayeva-Gupta, Y. Pancreatic cancer-associated inflammation drives dynamic regulation of p35 and Ebi3. Cytokine 2020, 125, 154817. [CrossRef]

134. Hou, Y.M.; Dong, J.; Liu, M.Y.; Yu, S. Expression of Epstein-Barr virus-induced gene 3 in cervical cancer: Association with clinicopathological parameters and prognosis. Oncol. Lett. 2016, 11, 330-334. [CrossRef]

135. Song, Q.; Chen, X.; Hu, W.; Mei, G.; Yang, X.; Wu, H. Downregulation of epstein-barr virus-induced gene 3 is associated with poor prognosis of hepatocellular carcinoma after curative resection. Oncol. Lett. 2018, 15, 7751-7759. [PubMed]

136. Kang, H.J.; Oh, J.H.; Chun, S.M.; Kim, D.; Ryu, Y.M.; Hwang, H.S.; Kim, S.Y.; An, J.; Cho, E.J.; Lee, H.; et al. Immunogenomic landscape of hepatocellular carcinoma with immune cell stroma and EBV-positive tumor-infiltrating lymphocytes. J. Hepatol. 2019, 71, 91-103. [CrossRef] [PubMed]

137. Nishizawa, T.; Okamoto, H.; Konishi, K.; Yoshizawa, H.; Miyakawa, Y.; Mayumi, M. A novel DNA virus (TTV) associated with elevated transaminase levels in posttransfusion hepatitis of unknown etiology. Biochem. Biophys. Res. Commun. 1997, 241, 92-97. [CrossRef]

138. Pineau, P.; Meddeb, M.; Raselli, R.; Qin, L.X.; Terris, B.; Tang, Z.Y.; Tiollais, P.; Mazzaferro, V.; Dejean, A. Effect of TT virus infection on hepatocellular carcinoma development: Results of a Euro-Asian survey. J. Infect. Dis. 2000, 181, 1138-1142. [CrossRef]

139. Tagger, A.; Donato, F.; Ribero, M.L.; Binelli, G.; Gelatti, U.; Portera, G.; Albertini, A.; Fasola, M.; Chiesa, R.; Nardi, G. A case-control study on a novel DNA virus (TT virus) infection and hepatocellular carcinoma. Hepatology 1999, 30, 294-299. [CrossRef] 
140. Yoshida, H.; Kato, N.; Shiratori, Y.; Lan, K.H.; Ono-Nita, S.K.; Feng, Z.; Shiina, S.; Omata, M. Poor association of TT virus viremia with hepatocellular carcinoma. Liver 2000, 20, 247-252. [CrossRef]

141. Hassoba, H.; Mahmoud, M.; Fahmy, H.; Leheta, O.; Sayed, A.; Fathy, A.; Serwah, A.; Abbas, A.; Nooman, Z.; Attia, F.; et al. TT Virus Infection Among Egyptian Patients With Hepatocellular Carcinoma. Egypt. J. Immunol. 2003, 10, 9-16.

142. Ahn, D.H.; Bekaii-Saab, T. Biliary cancer: Intrahepatic cholangiocarcinoma vs. extrahepatic cholangiocarcinoma vs. gallbladder cancers: Classification and therapeutic implications. J. Gastrointest. Oncol. 2017, 8, 239-301. [CrossRef]

143. Navas, M.C.; Glaser, S.; Dhruv, H.; Celinski, S.; Alpini, G.; Meng, F. Hepatitis C Virus Infection and Cholangiocarcinoma: An Insight into Epidemiologic Evidences and Hypothetical Mechanisms of Oncogenesis. Am. J. Pathol. 2019, 189, 1122-1132. [CrossRef]

144. Qu, Z.; Cui, N.; Qin, M.; Wu, X. Epidemiological survey of biomarkers of hepatitis virus in patients with extrahepatic cholangiocarcinomas. Asia. Pac. J. Clin. Oncol. 2012, 8, 83-87. [CrossRef]

145. Srivatanakul, P.; Honjo, S.; Kittiwatanachot, P.; Jedpiyawongse, A.; Khuhaprema, T.; Miwa, M. Hepatitis viruses and risk of cholangiocarcinoma in northeast Thailand. Asian Pac. J. Cancer Prev. 2010, 11, 985-988. [PubMed]

146. Perumal, V.; Wang, J.; Thuluvath, P.; Choti, M.; Torbenson, M. Hepatitis C and hepatitis B nucleic acids are present in intrahepatic cholangiocarcinomas from the United States. Hum. Pathol. 2006, 37, 1211-1216. [CrossRef]

147. Tan, J.H.; Zhou, W.Y.; Zhou, L.; Cao, R.C.; Zhang, G.W. Viral hepatitis B and C infections increase the risks of intrahepatic and extrahepatic cholangiocarcinoma: Evidence from a systematic review and meta-analysis. Turk. J. Gastroenterol. 2020, 31, 246-256. [CrossRef]

148. Ahn, C.S.; Hwang, S.; Lee, Y.J.; Kim, K.H.; Moon, D.B.; Ha, T.Y.; Song, G.W.; Lee, S.G. Prognostic impact of hepatitis B virus infection in patients with intrahepatic cholangiocarcinoma. ANZ J. Surg. 2018, 88, $212-217$. [CrossRef]

149. Jeong, S.; Gao, L.; Tong, Y.; Xia, L.; Xu, N.; Sha, M.; Zhang, J.; Kong, X.; Gu, J.; Xia, Q. Prognostic Impact of Cirrhosis in Patients With Intrahepatic Cholangiocarcinoma Following Hepatic Resection. Can. J. Gastroenterol. Hepatol. 2017, 2017, 6543423. [CrossRef] [PubMed]

150. Seo, J.W.; Kwan, B.S.; Cheon, Y.K.; Lee, T.Y.; Shim, C.S.; Kwon, S.Y.; Choe, W.H.; Yoo, B.C.; Yoon, J.M.; Lee, J.H. Prognostic impact of hepatitis B or C on intrahepatic cholangiocarcinoma. Korean J. Intern. Med. 2020, 35, 566-573. [CrossRef] [PubMed]

151. Tao, L.Y.; He, X.D.; Xiu, D.R. Hepatitis B virus is associated with the clinical features and survival rate of patients with intrahepatic cholangiocarcinoma. Clin. Res. Hepatol. Gastroenterol. 2016, 40, 682-687. [CrossRef] [PubMed]

152. Klufah, F.; Mobaraki, G.; Chteinberg, E.; Alharbi, R.A.; Winnepenninckx, V.; Speel, E.J.M.; Rennspiess, D.; Damink, S.W.O.; Neumann, U.P.; Kurz, A.K.; et al. High prevalence of human polyomavirus 7 in cholangiocarcinomas and adjacent peritumoral hepatocytes: Preliminary findings. Microorganisms 2020, 8 , 1125. [CrossRef]

153. Wang, Y.; Yang, S.; Song, F.; Cao, S.; Yin, X.; Xie, J.; Tu, X.; Xu, J.; Xu, X.; Dong, X.; et al. Hepatitis B virus status and the risk of pancreatic cancer: A meta-analysis. Eur. J. Cancer Prev. 2013, 22, 328-334. [CrossRef] [PubMed]

154. Abe, S.K.; Inoue, M.; Sawada, N.; Iwasaki, M.; Shimazu, T.; Yamaji, T.; Sasazuki, S.; Saito, E.; Tanaka, Y.; Mizokami, M.; et al. Hepatitis B and C virus infection and risk of pancreatic cancer: A population-based cohort study (JPHC study cohort II). Cancer Epidemiol. Biomarkers Prev. 2016, 25, 555-557. [CrossRef]

155. Zhu, F.; Li, H.; Du, G.; Chen, J.; Cai, S. Chronic Hepatitis B Virus Infection and Pancreatic Cancer: A Case-Control Study in Southern China. Asian Pac. J. Cancer Prev. 2011, 12, 1405-1408.

156. Chang, M.C.; Chen, C.H.; Liang, J.D.; Tien, Y.W.; Hsu, C.; Wong, J.M.; Chang, Y.T. Hepatitis B and C viruses are not risks for pancreatic adenocarcinoma. World J. Gastroenterol. 2014, 20, 5060-5065. [CrossRef]

157. Huang, J.; Magnusson, M.; Törner, A.; Ye, W.; Duberg, A.S. Risk of pancreatic cancer among individuals with hepatitis C or hepatitis B virus infection: A nationwide study in Sweden. Br. J. Cancer 2013, 109, 2917-2923. [CrossRef] [PubMed] 
158. Xu, J.H.; Fu, J.J.; Wang, X.L.; Zhu, J.Y.; Ye, X.H.; Chen, S.D. Hepatitis B or C viral infection and risk of pancreatic cancer: A meta-analysis of observational studies. World J. Gastroenterol. 2013, 19, 4234-4241. [CrossRef] [PubMed]

159. Tang, J.; Sharma, R.; Lamerato, L.; Sheehan, M.; Krajenta, R.; Gordon, S.C. Is previous exposure to hepatitis B a risk factor for pancreatic cancer or hepatocellular carcinoma? J. Clin. Gastroenterol. 2014, 48, 729-733. [CrossRef]

160. Andersen, E.S.; Omland, L.H.; Jepsen, P.; Krarup, H.; Christensen, P.B.; Obel, N.; Weis, N. Risk of all-type cancer, hepatocellular carcinoma, non-Hodgkin lymphoma and pancreatic cancer in patients infected with hepatitis B virus. J. Viral Hepat. 2015, 22, 828-834. [CrossRef]

161. Chen, Y.; Bai, X.; Zhang, Q.; Wen, L.; Su, W.; Fu, Q.; Sun, X.; Lou, Y.; Yang, J.; Zhang, J.; et al. The hepatitis $B$ virus $X$ protein promotes pancreatic cancer through modulation of the PI3K/AKT signaling pathway. Cancer Lett. 2016, 380, 98-105. [CrossRef] [PubMed]

162. Tomasiewicz, K.; Modrzewska, R.; Lyczak, A.; Krawczuk, G. TT virus infection and pancreatic cancer: Relationship or accidental coexistence. World J. Gastroenterol. 2005, 11, 2847-2849. [CrossRef]

163. Minton, K. Commensal viruses contribute to gut health. Nat. Rev. Immunol. 2019, 19, 721. [CrossRef]

164. Santiago-Rodriguez, T.M.; Hollister, E.B. Human virome and disease: High-throughput sequencing for virus discovery, identification of phage-bacteria dysbiosis and development of therapeutic approaches with emphasis on the human gut. Viruses 2019, 11, 656. [CrossRef]

165. Qiu, H.B.; Zhang, L.Y.; Zeng, Z.L.; Wang, Z.Q.; Luo, H.Y.; Keshari, R.P.; Zhou, Z.W.; Xu, R.H. HBV infection decreases risk of liver metastasis in patients with colorectal cancer: A cohort study. World J. Gastroenterol. 2011, 17, 804-808. [CrossRef]

166. Wang, F.S.; Shao, Z.G.; Zhang, J.L.; Liu, Y.F. Colorectal liver metastases rarely occur in patients with chronic hepatitis virus infection. Hepatogastroenterology 2012, 59, 1390-1392. [CrossRef] [PubMed]

167. Augustin, G.; Bruketa, T.; Korolija, D.; Milosevic, M. Lower incidence of hepatic metastases of colorectal cancer in patients with chronic liver diseases: Meta-analysis. Hepatogastroenterology. 2013, 60, 1164-1168. [PubMed]

168. Li Destri, G.; Castaing, M.; Ferlito, F.; Minutolo, V.; Di Cataldo, A.; Puleo, S. Rare hepatic metastases of colorectal cancer in livers with symptomatic HBV and HCV hepatitis. Ann. Ital. Chir. 2013, 84, 323-327.

169. García-Alonso, F.J.; Bonillo-Cambrodón, D.; Bermejo, A.; García-Martínez, J.; Hernández-Tejero, M.; Valer López Fando, P.; Piqueras, B.; Bermejo, F. Acceptance, yield and feasibility of attaching HCV birth cohort screening to colorectal cancer screening in Spain. Dig. Liver Dis. 2016, 48, 1237-1242. [CrossRef]

170. McGregor, B.; Byrne, P.; Kirgan, D.; Albright, J.; Manalo, P.; Hall, M. Confirmation of the association of human papillomavirus with human colon cancer. Am. J. Surg. 1993, 166, 738-742. [CrossRef]

171. Damin, D.C.; Caetano, M.B.; Rosito, M.A.; Schwartsmann, G.; Damin, A.S.; Frazzon, A.P.; Ruppenthal, R.D.; Alexandre, C.O.P. Evidence for an association of human papillomavirus infection and colorectal cancer. Eur. J. Surg. Oncol. 2007, 33, 569-574.

172. Giuliani, L.; Ronci, C.; Bonifacio, D.; Di Bonito, L.; Favalli, C.; Perno, C.; Syrjänen, K.; Ciotti, M. Detection of oncogenic DNA viruses in colorectal cancer. Anticancer Res. 2008, 28, 1405-1410. [PubMed]

173. Gornick, M.C.; Castellsague, X.; Sanchez, G.; Giordano, T.J.; Vinco, M.; Greenson, J.K.; Capella, G.; Raskin, L.; Rennert, G.; Gruber, S.B.; et al. Human papillomavirus is not associated with colorectal cancer in a large international study. Cancer Causes Control 2010, 21, 737-743. [PubMed]

174. Burnett-Hartman, A.N.; Feng, Q.; Popov, V.; Kalidindi, A.; Newcomb, P.A. Human papillomavirus DNA is rarely detected in colorectal carcinomas and not associated with microsatellite instability: The seattle colon cancer family registry. Cancer Epidemiol. Biomark. Prev. 2013, 22, 317-319.

175. Gazzaz, F.; Mosli, M.H.; Jawa, H.; Sibiany, A. Detection of human papillomavirus infection by molecular tests and its relation to colonic polyps and colorectal cancer. Saudi Med. J. 2016, 37, 256-261. [PubMed]

176. Mahmoudvand, S.; Safaei, A.; Erfani, N.; Sarvari, J. Presence of human papillomavirus DNA in colorectal cancer tissues in Shiraz, Southwest Iran. Asian Pac. J. Cancer Prev. 2015, 16, 7883-7887.

177. Qiu, Q.; Li, Y.; Fan, Z.; Yao, F.; Shen, W.; Sun, J.; Yuan, Y.; Chen, J.; Cai, L.; Xie, Y.; et al. Gene Expression Analysis of Human Papillomavirus-Associated Colorectal Carcinoma. Biomed. Res. Int. 2020, 2020, 5201587.

178. Asem, M.S.; Buechler, S.; Wates, R.B.; Miller, D.L.; Stack, M.S. Wnt5a signaling in cancer. Cancers 2016, 8, 79. [CrossRef] 
179. Smith, D.R.; Myint, T.; Goh, H.S. Over-expression of the c-myc proto-oncogene in colorectal carcinoma. Br. J. Cancer 1993, 68, 407-413.

180. Spandidos, D.; Yiagnisis, M.; Papadimitriou, K.; Field, J. ras, c-myc and c-erbB-2 oncoproteins in human breast cancer. Anticancer Res. 1989, 9, 1385-1393.

181. Little, C.D.; Nau, M.M.; Carney, D.N.; Gazdar, A.F.; Minna, J.D. Amplification and expression of the c-myc oncogene in human lung cancer cell lines. Nature 1983, 306, 194-196. [CrossRef] [PubMed]

182. Yoshimoto, K.; Hirohashi, S.; Sekiya, T. Increased expression of the c-myc gene without gene amplification in human lung cancer and colon cancer cell lines. Jpn. J. Cancer Res. GANN 1986, 77, 540-545. [PubMed]

183. Sun, D.W.; Zhang, Y.Y.; Qi, Y.; Zhou, X.T.; Lv, G.Y. Prognostic significance of MMP-7 expression in colorectal cancer: A meta-analysis. Cancer Epidemiol. 2015, 39, 135-142.

184. Otero, L.; Lacunza, E.; Vasquez, V.; Arbelaez, V.; Cardier, F.; González, F. Variations in AXIN2 predict risk and prognosis of colorectal cancer. BDJ Open 2019, 5, 13. [CrossRef] [PubMed]

185. Li, Y.X.; Zhang, L.; Simayi, D.; Zhang, N.; Tao, L.; Yang, L.; Zhao, J.; Chen, Y.Z.; Li, F.; Zhang, W.J. Human papillomavirus infection correlates with inflammatory stat 3 signaling activity and IL-17 level in patients with colorectal cancer. PLoS ONE 2015, 10, e0118391. [CrossRef] [PubMed]

186. Cao, K.; Tait, S.W.G. Apoptosis and Cancer: Force Awakens, Phantom Menace, or Both? Int. Rev. Cell Mol. Biol. 2018, 337, 135-152.

187. Karbasi, A.; Borhani, N.; Daliri, K.; Kazemi, B.; Manoochehri, M. Downregulation of external death receptor genes FAS and DR5 in colorectal cancer samples positive for human papillomavirus infection. Pathol. Res. Pract. 2015, 211, 444-448. [CrossRef]

188. Buyru, N.; Tezol, A.; Dalay, N. Coexistence of K-ras mutations and HPV infection in colon cancer. BMC Cancer 2006, 6, 115. [CrossRef]

189. Sayhan, N.; Yazici, H.; Budak, M.; Bitisik, O.; Dalay, N. P53 Codon 72 Genotypes in Colon Cancer. Association With Human Papillomavirus Infection. Res. Commun. Mol. Pathol. Pharmacol. 2001, 109, $25-34$.

190. Buyru, N.; Budak, M.; Yazici, H.; Dalay, N. p53 Gene Mutations Are Rare in Human Papillomavirus-Associated Colon Cancer. Oncol. Rep. 2003, 10, 2089-2092. [CrossRef]

191. Sarvari, J.; Mahmoudvand, S.; Pirbonyeh, N.; Safaei, A.; Hosseini, S.Y. The very low frequency of Epstein-Barr JC and BK viruses DNA in colorectal cancer tissues in Shiraz, Southwest Iran. Polish J. Microbiol. 2018, 67, 73-79. [CrossRef] [PubMed]

192. Malki, M.I.; Gupta, I.; Fernandes, Q.; Aboulkassim, T.; Yasmeen, A.; Vranic, S.; Al Moustafa, A.E.; Al-Thawadi, H.A. Co-presence of Epstein-Barr virus and high-risk human papillomaviruses in Syrian colorectal cancer samples. Hum. Vaccines Immunother. 2020, 1. [CrossRef] [PubMed]

193. Gupta, I.; Al Farsi, H.; Jabeen, A.; Skenderi, F.; Al-Thawadi, H.; Alahmad, Y.M.; Al Moustafa, A.E.; Vranic, S. High-risk human papillomaviruses and epstein-barr virus in colorectal cancer and their association with clinicopathological status. Pathogens 2020, 9, 456. [CrossRef] [PubMed]

194. Liang, Y.; Chen, Q.; Du, W.; Chen, C.; Li, F.; Yang, J.; Peng, J.; Kang, D.; Lin, B.; Chai, X.; et al. Epstein-Barr Virus-Induced Gene 3 (EBI3) Blocking Leads to Induce Antitumor Cytotoxic T Lymphocyte Response and Suppress Tumor Growth in Colorectal Cancer by Bidirectional Reciprocal-Regulation STAT3 Signaling Pathway. Mediat. Inflamm. 2016, 2016, 3214105.

195. Chen, H.P.; Jiang, J.K.; Chen, C.Y.; Chou, T.Y.; Chen, Y.C.; Chang, Y.T.; Lin, S.F.; Chan, C.H.; Yang, C.Y.; Lin, C.H.; et al. Human cytomegalovirus preferentially infects the neoplastic epithelium of colorectal cancer: A quantitative and histological analysis. J. Clin. Virol. 2012, 54, 240-244. [CrossRef]

196. Bai, B.; Wang, X.; Chen, E.; Zhu, H. Human cytomegalovirus infection and colorectal cancer risk: A meta-analysis. Oncotarget 2016, 7, 76735-76742. [CrossRef]

197. Chen, H.P.; Jiang, J.K.; Lai, P.Y.; Chen, C.Y.; Chou, T.Y.; Chen, Y.C.; Chan, C.H.; Lin, S.F.; Yang, C.Y.; Chen, C.Y.; et al. Tumoral presence of human cytomegalovirus is associated with shorter disease-free survival in elderly patients with colorectal cancer and higher levels of intratumoral interleukin-17. Clin. Microbiol. Infect. 2014, 20, 664-671. [CrossRef]

198. Knösel, T.; Schewe, C.; Dietel, M.; Petersen, I. Cytomegalovirus is not associated with progression and metastasis of colorectal cancer. Cancer Lett. 2004, 211, 243-247.

199. Mehrabani-Khasraghi, S.; Ameli, M.; Khalily, F. Demonstration of herpes simplex virus, cytomegalovirus, and Epstein-Barr virus in colorectal cancer. Iran. Biomed. J. 2016, 20, 302-306. 
200. Li, X.; Qian, D.; Ju, F.; Wang, B. Upregulation of Toll-like receptor 2 expression in colorectal cancer infected by human cytomegalovirus. Oncol. Lett. 2015, 9, 365-370. [CrossRef]

201. Harkins, L.; Volk, A.L.; Samanta, M.; Mikolaenko, I.; Britt, W.J.; Bland, K.I.; Cobbs, C.S. Specific localisation of human cytomegalovirus nucleic acids and proteins in human colorectal cancer. Lancet 2002, 360, 1557-1563. [CrossRef]

202. Sheng, J.; Sun, H.; Yu, F.-B.; Li, B.; Zhang, Y.; Zhu, Y.-T. The Role of Cyclooxygenase-2 in Colorectal Cancer. Int. J. Med. Sci. 2020, 17, 1095-1101. [CrossRef]

203. Teo, W.H.; Chen, H.P.; Huang, J.C.; Chan, Y.J. Human cytomegalovirus infection enhances cell proliferation, migration and upregulation of EMT markers in colorectal cancer-derived stem cell-like cells. Int. J. Oncol. 2017, 51, 1415-1426. [CrossRef] [PubMed]

204. Krishna, B.A.; Poole, E.L.; Jackson, S.E.; Smit, M.J.; Wills, M.R.; Sinclair, J.H. Latency-associated expression of human cytomegalovirus US28 attenuates cell signaling pathways to maintain latent infection. MBio 2017, 8. [CrossRef] [PubMed]

205. Cai, Z.Z.; Xu, J.G.; Zhou, Y.H.; Zheng, J.H.; Lin, K.Z.; Zheng, S.Z.; Ye, M.S.; He, Y.; Liu, C.B.; Xue, Z.X. Human cytomegalovirus-encoded US28 may act as a tumor promoter in colorectal cancer. World J. Gastroenterol. 2016, 22, 2789-2798. [CrossRef]

206. Langemeijer, E.V.; Slinger, E.; de Munnik, S.; Schreiber, A.; Maussang, D.; Vischer, H.; Verkaar, F.; Leurs, R.; Siderius, M.; Smit, M.J. Constitutive B-Catenin Signaling by the Viral Chemokine Receptor US28. PLoS ONE 2012, 7, e48935. [CrossRef] [PubMed]

207. Maussang, D.; Langemeijer, E.; Fitzsimons, C.P.; Stigter-van Walsům, M.; Dijkman, R.; Borg, M.K.; Slinger, E.; Schreiber, A.; Michel, D.; Tensen, C.P.; et al. The human cytomegalovirus-encoded chemokine receptor US28 promotes angiogenesis and tumor formation via cyclooxygenase-2. Cancer Res. 2009, 69, 2861-2869. [CrossRef]

208. Zu Rhein, G.M.; Chou, S.M. Particles resembling papova viruses in human cerebral demyelinating disease. Science (80-.) 1965, 148, 1477-1479. [CrossRef]

209. Coelho, T.R.; Almeida, L.; Lazo, P.A. JC virus in the pathogenesis of colorectal cancer, an etiological agent or another component in a multistep process? Virol. J. 2010, 7, 42. [CrossRef]

210. Mou, X.; Chen, L.; Liu, F.; Lin, J.; Diao, P.; Wang, H.; Li, Y.; Lin, J.; Teng, L.; Xiang, C. Prevalence of JC virus in chinese patients with colorectal cancer. PLoS ONE 2012, 7, e35900. [CrossRef]

211. Shavaleh, R.; Kamandi, M.; Feiz Disfani, H.; Mansori, K.; Naseri, S.N.; Rahmani, K.; Ahmadi Kanrash, F. Association between JC virus and colorectal cancer: Systematic review and meta-analysis. Infect. Dis. (Auckl.) 2020, 52, 152-160. [CrossRef] [PubMed]

212. Newcomb, P.A.; Bush, A.; Stoner, G.; Lampe, J.; Potter, J.; Bigler, J. No Evidence of an Association of JC Virus and Colon Neoplasia. Cancer Epidemiol. Biomark. Prev. 2004, 13, 662-666.

213. Lundstig, A.; Stattin, P.; Persson, K.; Sasnauskas, K.; Viscidi, R.P.; Gislefoss, R.E.; Dillner, J. No excess risk for colorectal cancer among subjects seropositive for the JC polyomavirus. Int. J. Cancer 2007, 121, 1098-1102. [CrossRef]

214. Hampras, S.S.; Viscidi, R.P.; Helzlsouer, K.J.; Lee, J.H.; Fulp, W.J.; Giuliano, A.R.; Platz, E.A.; Rollison, D.E. Prospective study of seroreactivity to JC virus T-antigen and risk of colorectal cancers and adenomas. Cancer Epidemiol. Biomark. Prev. 2014, 23, 2591-2596. [CrossRef] [PubMed]

215. Esmailzadeh, N.; Ranaee, M.; Alizadeh, A.; Khademian, A.; Saber Amoli, S.; Sadeghi, F. Presence of JC Polyomavirus in Nonneoplastic Inflamed Colon Mucosa and Primary and Metastatic Colorectal Cancer. Gastrointest. Tumors 2020, 7, 30-40. [CrossRef] [PubMed]

216. Goel, A.; Li, M.S.; Nagasaka, T.; Shin, S.K.; Fuerst, F.; Ricciardiello, L.; Wasserman, L.; Boland, C.R. Association of JC Virus T-Antigen Expression With the Methylator Phenotype in Sporadic Colorectal Cancers. Gastroenterology 2006, 130, 1950-1961. [CrossRef]

217. Ricciardiello, L.; Baglioni, M.; Giovannini, C.; Pariali, M.; Cenacchi, G.; Ripalti, A.; Landini, M.; Sawa, H.; Nagashima, K.; Frisque, R.; et al. Induction of chromosomal instability in colonic cells by the human polyomavirus JC virus. Cancer Res. 2003, 63, 7256-7262.

218. Niv, Y.; Vilkin, A.; Brenner, B.; Kendel, Y.; Morgenstern, S.; Levi, Z. HMLH1 promoter methylation and JC virus $\mathrm{T}$ antigen presence in the tumor tissue of colorectal cancer Israeli patients of different ethnic groups. Eur. J. Gastroenterol. Hepatol. 2010, 22, 938-941. [CrossRef] 
219. Vilkin, A.; Ronen, Z.; Levi, Z.; Morgenstern, S.; Halpern, M.; Niv, Y. Presence of JC virus DNA in the tumor tissue and normal mucosa of patients with sporadic colorectal cancer (CRC) or with positive family history and Bethesda criteria. Dig. Dis. Sci. 2012, 57,79-84. [CrossRef]

220. Coelho, T.R.; Gaspar, R.; Figueiredo, P.; Mendonça, C.; Lazo, P.A.; Almeida, L. Human JC polyomavirus in normal colorectal mucosa, hyperplastic polyps, sporadic adenomas, and adenocarcinomas in Portugal. J. Med. Virol. 2013, 85, 2119-2127. [CrossRef]

221. Staib, C.; Pesch, J.; Gerwig, R.; Gerber, J.K.; Brehm, U.; Stangl, A.; Grummt, F. p53 inhibits JC virus DNA replication in vivo and interacts with JC virus large T-antigen. Virology 1996, 219, 237-246. [CrossRef] [PubMed]

222. Link, A.; Shin, S.K.; Nagasaka, T.; Balaguer, F.; Koi, M.; Jung, B.; Richard Boland, C.; Goel, A. JC virus mediates invasion and migration in colorectal metastasis. PLoS ONE 2009, 4, e8146. [CrossRef]

223. Enam, S.; Del Valle, L.; Lara, C.; Gan, D.-D.; Ortiz-Hidalgo, C.; Palazzo, J.P.; Khalili, K. Association of Human Polyomavirus JCV With Colon Cancer: Evidence for Interaction of Viral T-antigen and Beta-Catenin. Cancer Res. 2002, 62, 7093-7101. [PubMed]

224. Enam, S.; Gan, D.-D.; White, M.K.; Del Valle, L.; Khalili, K. Regulation of Human Neurotropic JCV in Colon Cancer Cells. Anticancer Res. 2006, 26, 833-841. [PubMed]

225. Ripple, M.J.; Struckhoff, A.P.; Trillo-Tinoco, J.; Li, L.; Margolin, D.A.; McGoey, R.; Valle, L. Del Activation of c-Myc and cyclin D1 by JCV T-Antigen and $\beta$-Catenin in colon cancer. PLoS ONE 2014, 9, e106257. [CrossRef]

226. Nosho, K.; Shima, K.; Kure, S.; Irahara, N.; Baba, Y.; Chen, L.; Kirkner, G.J.; Fuchs, C.S.; Ogino, S. JC virus T-antigen in colorectal cancer is associated with p53 expression and chromosomal instability, independent of CpG island methylator phenotype. Neoplasia 2009, 11, 87-95. [CrossRef]

227. Hoff, P.M.; Coudry, R.; Moniz, C.M.V. Pathology of Anal Cancer. Surg. Oncol. Clin. N. Am. 2017, $26,57-71$. [CrossRef]

228. Kang, Y.J.; Smith, M.; Canfell, K. Anal cancer in high-income countries: Increasing burden of disease. PLoS ONE 2018, 13, e0205105. [CrossRef]

229. Frisch, M.; Fenger, C.; van den Brule, A.; Sørensen, P.; Meijer, C.; Walboomers, J.; Adami, H.; Melbye, M.; Glimelius, B. Variants of squamous cell carcinoma of the anal canal and perianal skin and their relation to human papillomaviruses. Cancer Res. 1999, 59, 753-757.

230. Silva Dalla Libera, L.; Almeida de Carvalho, K.; Enocencio Porto Ramos, J.; Oliveira Cabral, L.; de Cassia Goncalves de Alencar, R.; Villa, L.; Alves, R.; Rabelo Santos, S.; Aparecida Dos Santos Carneiro, M.; Saddi, V. Human Papillomavirus and Anal Cancer: Prevalence, Genotype Distribution, and Prognosis Aspects From Midwestern Region of Brazil. J. Oncol. 2019, 2019, 6018269. [CrossRef]

231. Urbute, A.; Rasmussen, C.L.; Belmonte, F.; Obermueller, T.; Prigge, E.S.; Arbyn, M.; Verdoodt, F.; Kjaer, S.K. Prognostic significance of HPV DNA and p16INK4a in anal cancer: A systematic review and meta-analysis. Cancer Epidemiol. Biomark. Prev. 2020, 29, 703-710. [CrossRef]

232. Koerber, S.A.; Schoneweg, C.; Slynko, A.; Krug, D.; Haefner, M.F.; Herfarth, K.; Debus, J.; Sterzing, F.; Von Knebel Doeberitz, M.; Prigge, E.S.; et al. Influence of human papillomavirus and p16INK4a on treatment outcome of patients with anal cancer. Radiother. Oncol. 2014, 113, 331-336. [CrossRef] [PubMed]

233. Rödel, F.; Wieland, U.; Fraunholz, I.; Kitz, J.; Rave-Fränk, M.; Wolff, H.A.; Weiss, C.; Wirtz, R.; Balermpas, P.; Fokas, E.; et al. Human papillomavirus DNA load and p16INK4a expression predict for local control in patients with anal squamous cell carcinoma treated with chemoradiotherapy. Int. J. Cancer 2015, 136, 278-288. [CrossRef] [PubMed]

234. Mai, S.; Welzel, G.; Ottstadt, M.; Lohr, F.; Severa, S.; Prigge, E.S.; Wentzensen, N.; Trunk, M.J.; Wenz, F.; Von Knebel-Doeberitz, M.; et al. Prognostic relevance of HPV infection and p16 overexpression in squamous cell anal cancer. Int. J. Radiat. Oncol. Biol. Phys. 2015, 93, 819-827. [CrossRef]

235. Małusecka, E.; Chmielik, E.; Suwiński, R.; Giglok, M.; Lange, D.; Rutkowski, T.; Mazurek, A.M. Significance of HPV16 Viral Load Testing in Anal Cancer. Pathol. Oncol. Res. 2020, 26, 2191-2199. [CrossRef] [PubMed]

236. Rademacher, B.L.; Matkowskyj, K.A.; Meske, L.M.; Romero, A.; Sleiman, H.; Carchman, E.H. The role of pharmacologic modulation of autophagy on anal cancer development in an HPV mouse model of carcinogenesis. Virology 2017, 507, 82-88. [CrossRef] [PubMed]

237. Rademacher, B.L.; Matkowskyj, K.A.; Lacount, E.D.; Carchman, E.H. Topical application of a dual PI3K/mTOR inhibitor prevents anal carcinogenesis in a human papillomavirus mouse model of anal cancer. Eur. J. Cancer Prev. 2019, 28, 483-491. [CrossRef] 
238. Wechsler, E.I.; Tugizov, S.; Herrera, R.; Da Costa, M.; Palefsky, J.M. E5 can be expressed in anal cancer and leads to epidermal growth factor receptor-induced invasion in a human papillomavirus 16-transformed anal epithelial cell line. J. Gen. Virol. 2018, 99, 631-644. [CrossRef] [PubMed]

239. Salit, I.E.; Tinmouth, J.; Chong, S.; Raboud, J.; Diong, C.; Su, D.S.; Sano, M.; Lytwyn, A.; Chapman, W.; Mahony, J. Screening for HIV-associated anal cancer: Correlation of HPV genotypes, p16, and E6 transcripts with anal pathology. Cancer Epidemiol. Biomark. Prev. 2009, 18, 1986-1992. [CrossRef] [PubMed]

240. Thomas, M.K.; Pitot, H.C.; Liem, A.; Lambert, P.F. Dominant role of HPV16 E7 in anal carcinogenesis. Virology 2011, 421, 114-118. [CrossRef]

241. Da Silva Neto, M.M.; Brites, C.; Borges, Á.H. Cancer during HIV infection. APMIS 2020, 128, 121-128. [CrossRef]

242. Silverberg, M.; Lau, B.; Justice, A.; Engels, E.; Gill, M.; Goedert, J.; Kirk, G.; D’Souza, G.; Bosch, R.; Brooks, J.; et al. Risk of anal cancer in HIV-infected and HIV-uninfected individuals in North America. Clin. Infect. Dis. 2012, 54, 1026-1034. [CrossRef] [PubMed]

243. Wentzensen, N.; Follansbee, S.; Borgonovo, S.; Tokugawa, D.; Schwartz, L.; Lorey, T.S.; Sahasrabuddhe, V.V.; Lamere, B.; Gage, J.C.; Fetterman, B.; et al. Human papillomavirus genotyping, human papillomavirus mRNA expression, and p16/Ki-67 cytology to detect anal cancer precursors in HIV-infected MSM. AIDS 2012, 26, 2185-2192. [CrossRef] [PubMed]

244. Combes, J.D.; Clifford, G.M.; Günthard, H.F.; Hauser, C.; Darling, K.E.A.; Valladares, P.; Battegay, M.; Waldeck, F.; Bernasconi, E.; Bertisch, B.; et al. Antibodies against HPV16E6 oncoprotein in the Swiss HIV cohort study: Kinetics and anal cancer risk prediction. Int. J. Cancer 2020, 147, 757-765. [CrossRef] [PubMed]

245. Bertisch, B.; Franceschi, S.; Lise, M.; Vernazza, P.; Keiser, O.; Schöni-Affolter, F.; Bouchardy, C.; Dehler, S.; Levi, F.; Jundt, G.; et al. Risk factors for anal cancer in persons infected with HIV: A nested case-control study in the Swiss HIV Cohort Study. Am. J. Epidemiol. 2013, 178, 877-884. [CrossRef]

246. Meyer, J.E.; Panico, V.J.A.; Marconato, H.M.F.; Sherr, D.L.; Christos, P.; Pirog, E.C. HIV positivity but not $\mathrm{HPV} / \mathrm{p} 16$ status is associated with higher recurrence rate in anal cancer. J. Gastrointest. Cancer 2013, 44, 450-455. [CrossRef]

247. Liu, Y.; Sigel, K.M.; Westra, W.; Gitman, M.R.; Zheng, W.; Gaisa, M.M. HIV-Infected Patients With Anal Cancer Precursors: Clinicopathological Characteristics and Human Papillomavirus Subtype Distribution. Dis. Colon Rectum 2020, 63, 890-896. [CrossRef]

248. De Martel, C.; Georges, D.; Bray, F.; Ferlay, J.; Clifford, G.M. Global burden of cancer attributable to infections in 2018: A worldwide incidence analysis. Lancet Glob. Health 2020, 8, e180-e190. [CrossRef]

249. Kannen, V.; Parry, L.; Martin, F.L. Phages Enter the Fight against Colorectal Cancer. Trends Cancer 2019, 5, 577-579. [CrossRef] [PubMed]

Publisher's Note: MDPI stays neutral with regard to jurisdictional claims in published maps and institutional affiliations.

(C) 2020 by the authors. Licensee MDPI, Basel, Switzerland. This article is an open access article distributed under the terms and conditions of the Creative Commons Attribution (CC BY) license (http://creativecommons.org/licenses/by/4.0/). 